\title{
Multi-temporal scale changes of streamflow and sediment load in a loess hilly watershed of China
}

\author{
Guangyao Gao, ${ }^{1,3}$ Ying $\mathrm{Ma}^{2 *}$ and Bojie $\mathrm{Fu}^{1,3}$ \\ ${ }^{1}$ State Key Laboratory of Urban and Regional Ecology, Research Center for Eco-Environmental Sciences, Chinese Academy of Sciences, Beijing \\ 100085, China \\ ${ }^{2}$ Key Laboratory of Water Cycle and Related Land Surface Processes, Institute of Geographic Sciences and Natural Resources Research, Chinese \\ Academic of Sciences, Beijing 100101, China \\ ${ }^{3}$ Joint Center for Global Change Studies, Beijing 100875, China
}

\begin{abstract}
:
Global climate change and diverse human activities have resulted in distinct temporal-spatial variability of watershed hydrological regimes, especially in water-limited areas. This study presented a comprehensive investigation of streamflow and sediment load changes on multi-temporal scales (annual, flood season, monthly and daily scales) during 1952-2011 in the Yanhe watershed, Loess Plateau. The results indicated that the decreasing trend of precipitation and increasing trend of potential evapotranspiration and aridity index were not significant. Significant decreasing trends $(p<0.01)$ were detected for both the annual and flood season streamflow, sediment load, sediment concentration and sediment coefficient. The runoff coefficient exhibited a significantly negative trend $(p<0.01)$ on the flood season scale, whereas the decreasing trend on the annual scale was not significant. The streamflow and sediment load during July-August contributed $46.7 \%$ and $86.2 \%$ to the annual total, respectively. The maximum daily streamflow and sediment load had the median occurrence date of July 31 , and they accounted for $9.7 \%$ and $29.2 \%$ of the annual total, respectively. All of these monthly and daily hydrological characteristics exhibited remarkable decreasing trends $(p<0.01)$. However, the contribution of the maximum daily streamflow to the annual total progressively decreased $\left(-0.07 \%\right.$ year $\left.^{-1}\right)$, while that of maximum daily sediment load increased over the last 60 years $(0.08 \%$ year $^{-1}$ ). The transfer of sloping cropland for afforestation and construction of check-dams represented the dominant causes of streamflow and sediment load reductions, which also made the sediment grain finer. Copyright @ 2015 John Wiley \& Sons, Ltd.
\end{abstract}

KEY WORDS streamflow; sediment load; multi-temporal scale; change analysis; the Loess Plateau

Received 27 March 2015; Accepted 17 June 2015

\section{INTRODUCTION}

The integrated consequences of climate change and diverse human activities have led to the considerable global alterations of fluvial hydrological regimes during recent decades (Milly et al., 2005; Cohen et al., 2014). Apparent decreasing and increasing trends in streamflow and sediment load have been reported in many basins around the world (Walling and Fang, 2003; Milly et al., 2005). To effectively utilize water resources and reasonably manage river flows, it is essential to investigate the historical changes of runoff and sediment load on different temporal and spatial scales, and to examine the reasons for the significant changes.

*Correspondence to: Ying Ma, Key Laboratory of Water Cycle and Related Land Surface Processes, Institute of Geographic Sciences and Natural Resources Research, Chinese Academic of Sciences, Beijing 100101, China.

E-mail: maying@igsnrr.ac.cn
On the global scale, Milliman et al. (2008) found that approximately one-third of 137 world-representative rivers exhibited more than a $30 \%$ change in annual discharge, and they identified the climatic and anthropogenic factors affecting river discharge in the three distinct river types, i.e. normal, deficit and excess. Walling and Fang (2003) reported that nearly $50 \%$ of 145 major global rivers showed significant increasing or decreasing trends in sediment load. Land clearance for agriculture and other facts of land surface disturbances were the key drivers of increased sediment loads, and the trapping of sediment by dams represented the dominant cause of reduced loads (Walling and Fang, 2003). Moreover, Xu et al. (2010) investigated the temporal trend of annual precipitation and runoff in five major Chinese rivers during 1951-2000 and indicated the significantly different hydrological regime changes and human activity roles in northern and southern rivers. Chu et al. (2009) estimated that dams and reservoirs, soil and water conservation, water consumption and in-channel sand mining accounted for $56 \%, 23 \%, 15 \%$ and $6 \%$ of the 
total sediment reduction by human activities for nine major Chinese rivers during 1959-2007, respectively. Changes in streamflow and sediment load have intensified stresses on natural and human-management ecosystems, especially for regions with limited water resources, e.g. the Loess Plateau in China.

The Loess Plateau region with a total area of 0.64 million $\mathrm{km}^{2}$ is located in the middle reaches of the Yellow River basin (MRYRB) in Northern China. This region experiences arid and semi-arid climate conditions. Moreover, the Loess Plateau region is one of the most severely eroded areas in the world because of highly erodible loessial soil, steep topography, frequent heavy rainfall in summer months, and sparse vegetation stemming from intensive cultivation and improper land uses (Zhang et al., 2008). The high rates of soil erosion and sediment transport have not only aggravated the local fragile ecological environment but have also negative off-site effects (Rustomji et al., 2008; Peng et al., 2010). Large amounts of sediment deposited in the lower reaches of the Yellow River have aggraded the riverbed by $8-10 \mathrm{~m}$ above the surrounding floodplain, which poses a major flood hazard to local communities (Peng et al., 2010).

To control the severe soil erosion in the Loess Plateau, several soil conservation measures have been implemented since the 1950s. These measures consist of afforestation, pasture reestablishment, terrace building and check-dam constructing (Ran et al., 2000, 2012). A recent large reforestation campaign, the Grain-for-Green (GFG) project, was implemented at the end of the 1990s, aiming to convert steep croplands to forest and pasture lands (Feng et al., 2012). Meanwhile, the Loess Plateau region has been experiencing a climatic warming and drying trend since the 1950s. Previous work has shown that the region-averaged annual mean temperature has significantly increased over the last 50years during $1961-2010\left(0.04{ }^{\circ} \mathrm{C}_{\text {year }}{ }^{-1}\right)$, whereas the region-averaged annual precipitation has exhibited a non-significant negative trend $\left(-0.58 \mathrm{~mm} \mathrm{year}^{-1}\right)$ (Wang et al., 2012). The average annual reference evapotranspiration has increased significantly by $1.31 \mathrm{~mm}^{-1}$ yer $^{-1}$ as a result of the downward trend in relative humidity and upward trend in temperature on the Loess Plateau during 1961-2009 (Li et al., 2012).

The extensive land-use and land-cover changes caused by the soil and water conservation measures and direct human activities, such as reservoir construction, irrigation and water abstraction, combined with climate variability, have dramatically altered the hydrological regimes of many watersheds in the Loess Plateau (Wang et al., 2013; Gao et al., 2013). Significant negative trends of -0.13 to $-1.58 \mathrm{~mm}^{-1} \mathrm{year}^{-1}$ in annual streamflow were detected during 1950s-2000 in 11 catchments within the central region of the Loess Plateau, and the land-use and landcover changes accounted for more than $50 \%$ of the reduction in the mean annual streamflow in 8 out of the 11 studied catchments (Zhang et al., 2008). All the 11 catchments in Zhang et al. (2008) experienced significant reduction in annual sediment yield from $-0.03 \times 10^{3}$ to $-0.42 \times 10^{3} \mathrm{t} \mathrm{km}^{-2}$ years $^{-1}$, and soil conservation practices typically accounted for $\sim 75 \%$ of the observed reductions (Rustomji et al., 2008). Furthermore, the components of runoff (surface runoff and baseflow), streamflow regime and the dynamic relationship between streamflow and sediment load in the catchments of the Loess Plateau also exhibited evident changes (Dou et al., 2009; Mu et al., 2007; Gao et al., 2012; Gao et al., 2014).

It is certain that the aforementioned studies have provided substantial insight into the streamflow and sediment load changes in the Loess Plateau. However, most of the previous studies usually focused on the annual streamflow and sediment load changes, while some studies examined changes on flood season scale (Gao et al., 2013). In reality, most of the runoff in the Loess Plateau is generated during June-September, especially due to a few intense rainstorms. During the past 50 years, more precipitation over the Loess Plateau tended to occur only during several extreme events, which produced an increasing trend in precipitation erosivity (Wan et al., 2014). A large proportion of total fluvial sediment loads were commonly observed during relatively short-duration floods when both the streamflow and sediment concentration are highest (Rustomji et al., 2008). For example, approximately $50-99 \%$ of each year's sediment load from the Gushan and Weifen Rivers in the Coarse Sandy Hilly Catchments region was typically transported within 5 days of reaching the maximum streamflow (Rustomji et al., 2008). Therefore, the most critical examination should be on monthly and extreme daily hydrological regime variations during the flood season. Furthermore, the primary variables considered in previous studies included streamflow, sediment load, precipitation and temperature. These variables may not fully reflect the observed runoff and sediment changes or the effects of climate variability.

To overcome the aforementioned weaknesses, the annual, flood season (June-September) and monthly climatic (i.e. precipitation, temperature, relative humidity, potential evapotranspiration and aridity index) and hydrological (i.e. streamflow, sediment load, sediment concentration, runoff coefficient and sediment coefficient) data combined with extreme daily variables (i.e. maximum daily discharge, sediment discharge and sediment concentration for each year) during 1952-2011 were collected in a typical hilly-gully watershed (Yanhe watershed) of the Loess Plateau. The specific objectives were to (1) detect the streamflow and sediment load changes in the Yanhe watershed on multi-temporal scales and investigate the relationships between the changes on different scales and (2) determine the quantitative contributions and detailed 
effects of climate variability and human activities on streamflow and sediment load changes.

\section{STUDY AREA AND DATA}

\section{Study area}

The Yanhe River with a length of $284.3 \mathrm{~km}$ is a firstorder tributary of the Yellow River. The Yanhe watershed $\left(108^{\circ} 38^{\prime}-110^{\circ} 29^{\prime} \mathrm{E}, 36^{\circ} 21^{\prime}-37^{\circ} 19^{\prime} \mathrm{N}\right)$ is located in the central region of the Loess Plateau in northern Shaanxi Province, China (Figure 1). The area of the watershed is $7725 \mathrm{~km}^{2}$. The landform is a typical loess hilly/gullied landscape with elevations ranging from 495 to $1795 \mathrm{~m}$ above sea level, while the gully density ranges from 2.1 to $4.6 \mathrm{~km} \mathrm{~km}^{-2}$. The average slope of the region is $23.4^{\circ}$. The most common soil in the watershed is loess, which is an erosion-prone fine silt soil. The watershed has a typical semiarid continental climate. The average annual precipitation (1952-2011) is $~ 500 \mathrm{~mm} \mathrm{a}^{-1}$ with $70 \%$ of precipitation falls from June to September. Moreover, the average potential evapotranspiration is $\sim 960 \mathrm{~mm} \mathrm{a}^{-1}$ for the same period and the average temperature is $9.7^{\circ} \mathrm{C}$. Forestland, grassland and cropland are the three dominant land use types in the study area.

\section{Data sources}

The monthly streamflow, sediment load and sediment concentration data (1952-2011) at the Ganguyi hydrological station (GHS, $109^{\circ} 48^{\prime} \mathrm{E}, 36^{\circ} 42^{\prime} \mathrm{E}, 900 \mathrm{~m}$ altitude) with control area of $5891 \mathrm{~km}^{2}$ were obtained from the Bureau of Hydrology, Yellow River Conservancy Commission, China. The Ganguyi is the final hydrolog- ical station in the Yanhe River. Daily precipitation from 1952-2011 at 39 rain gauge stations inside the watershed were also provided by this institute. Daily climate data from 1952 to 2011 at the five county-level meteorological stations (i.e. Ansai, Yan'an, Yanchang, Zhidan, and Jingbian) in and around the watershed were obtained from the Shaanxi Meteorological Administration, China. Seven meteorological variables, including the mean, maximum and minimum air temperatures, vapour pressure, relative humidity, wind speed at 2-m height, and bright sunshine hours, were used to calculate the potential evapotranspiration. The locations of the hydrological, rain gauge and meteorological stations were shown in Figure 1. All the measured data were checked by the corresponding agencies and rated as good quality.

Data of the soil and water conservation measures from 1959 to 2006 were obtained from Ran et al. $(2000,2012)$ based on on-site field surveys and observations. The data included the areas of afforestation, grass-planting, level terraces and check-dams and the siltation of check dams, reservoirs and gully control projects. The land-use data in 1975, 1990 and 2000 were interpreted from remotely sensed Landsat images with a map scale of 1:100000. The land cover classification in 2008 was updated using China-Brazil Earth Resources Satellite (CBERS-2b) images with a ground resolution of $20 \mathrm{~m}$.

\section{Climate and hydrological variables}

Climate variables. The precipitation $(P, \mathrm{~mm})$, mean, maximum and minimum air temperature ( $T_{\text {mean }}, T_{\max }$ and $\left.T_{\min },{ }^{\circ} \mathrm{C}\right)$ and relative humidity $(R H, \%)$ were chosen as the climate variables for analysis in this study. To reflect the complete effect of meteorological variables, the

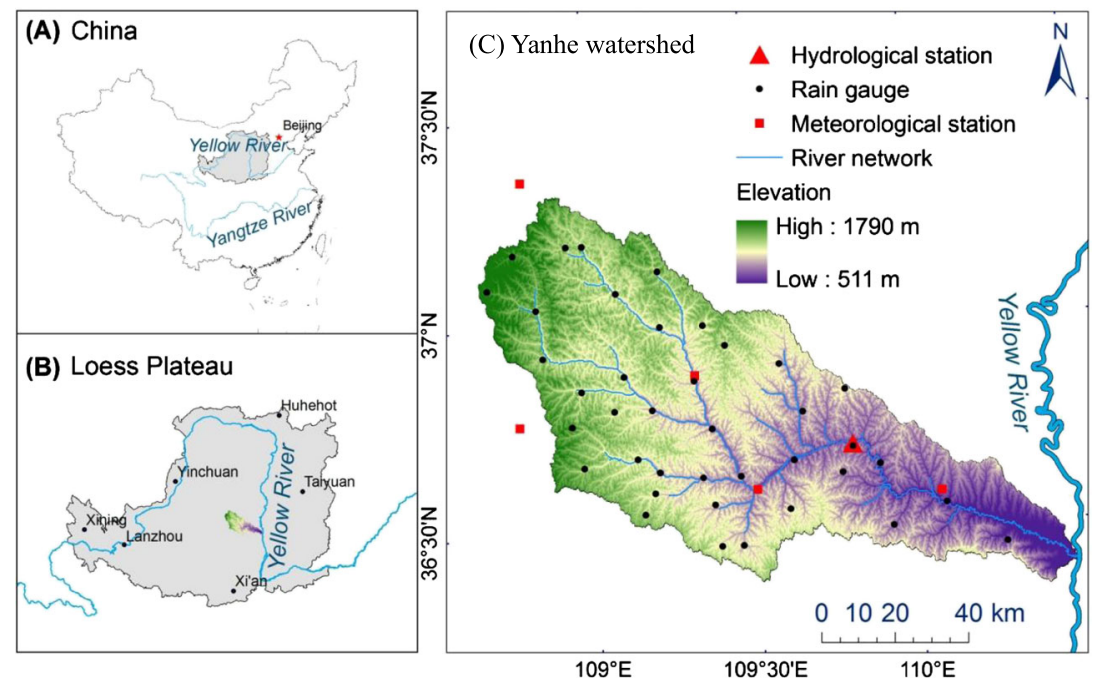

Figure 1. (a) The location of the Loess Plateau (grey shading) in the middle reaches of the Yellow River Basin, China. (b) Location of the Yanhe watershed (colour shading) in the middle part of the Loess Plateau. (c) An overview of the Yanhe watershed 
potential evapotranspiration (PET, $\mathrm{mm})$ and aridity index $(A I)$ were also analysed. The $A I$ was expressed as the ratio of the difference between $P E T$ and $P$ versus PET (i.e. $A I=(P E T-P) / P E T)$ (Thornthwaite, 1948). The $A I$ can be understood as the water requirement to satisfy the potential evapotranspiration. If $P$ is equal to or exceeds the $P E T$, the $A I$ is equivalent to zero or is negative. In contrast, the positive $A I$ values indicate the dry conditions in the watershed, and the $A I$ approaches 1 in the absence of precipitation.

For further analysis, the daily $P$ and PET data were aggregated to monthly, flood season and annual totals, and the corresponding $A I$ values were calculated from the aggregated data. The monthly, flood season and annual values of $T_{\text {mean }}, T_{\max }, T_{\min }$ and $R H$ were obtained by averaging the measured daily data on corresponding temporal scales. The watershed-wide area-average climate variables were calculated using the Thiessen Polygon method to account for the spatial variability in the study area.

Hydrological variables. To fully reflect the hydrological characteristics of the watershed, the changes of streamflow $\left(R, \mathrm{~m}^{3}\right)$, sediment load $(S, \mathrm{t})$, sediment concentration $\left(S C=S / R, \mathrm{~kg} \mathrm{~m}^{-3}\right)$, runoff coefficient $\left(C_{\mathrm{r}}=R /(A . P)\right.$, where $A$ is the control area of hydrological station, $\left.\mathrm{km}^{2}\right)$ and sediment coefficient $\left(C_{\mathrm{s}}=S /(A . P), \mathrm{t} \mathrm{km}^{-2} \mathrm{~mm}^{-1}\right)$ (Liu et al., 2014) on monthly, flood season and annual scales were analysed. The $C_{\mathrm{r}}$ and $C_{\mathrm{s}}$ signify runoff and sediment availability per unit area per unit precipitation in the watershed during a given period, respectively.

In the Loess Plateau, a large proportion of annual streamflow and sediment load was typically produced by a few intense rainstorms. It is critical to examine the variations of high daily streamflow and sediment load. Therefore, the maximum daily discharge $\left(Q_{\mathrm{md}}, \mathrm{m}^{3} \mathrm{~s}^{-1}\right)$, sediment discharge $\left(Q_{\mathrm{smd}}, \mathrm{t} \mathrm{s}^{-1}\right)$ and sediment concentration $\left(S C_{\mathrm{md}}, \mathrm{kg} \mathrm{m}^{-3}\right)$ during each year were chosen as the hydrological variables on the daily scale. The interannual changes in the percentages of maximum daily streamflow $\left(P_{\mathrm{Rmd}}=864 Q_{\mathrm{md}} / R, \%\right)$ and sediment load $\left(P_{\text {Smd }}=864 Q_{\text {smd }} / S, \%\right)$ accounting for the annual total were also analysed.

\section{METHOLOGY}

\section{Potential evapotranspiration}

The daily potential evapotranspiration was calculated using the FAO Penman-Monteith method (Allen et al., 1998):

$$
P \mathrm{ET}=\frac{0.408 \Delta\left(R_{\mathrm{n}}-G\right)+\gamma \frac{900}{T_{\mathrm{a}}+273} u_{2}\left(e_{\mathrm{s}}-e_{\mathrm{a}}\right)}{\Delta+\gamma\left(1+0.34 u_{2}\right)}
$$

where $R_{\mathrm{n}}$ was net radiation at the crop surface $\left(\mathrm{MJ} \mathrm{m}^{-2} \mathrm{day}^{-1}\right), G$ was soil heat flux density $\left(\mathrm{MJ} \mathrm{m}^{-2} \mathrm{day}^{-1}\right), T_{\mathrm{a}}$ was mean air temperature at $2 \mathrm{~m}$ height $\left({ }^{\circ} \mathrm{C}\right), u_{2}$ was wind speed at $2 \mathrm{~m}$ height $\left(\mathrm{ms}^{-1}\right), e_{\mathrm{s}}$ was saturation vapour pressure $(\mathrm{KPa}), e_{\mathrm{a}}$ was actual vapour pressure $(\mathrm{KPa}), \Delta$ was slope vapour pressure curve $\left(\mathrm{KPa}^{\circ} \mathrm{C}^{-1}\right)$ and $\gamma$ was the psychrometric constant $\left(\mathrm{KPa}^{\circ} \mathrm{C}^{-1}\right)$. A complete set of equations were proposed by Allen et al. (1998) to compute the parameters in Equation (1).

\section{Trend test}

The Mann-Kendall (M-K) method, which was originally proposed by Mann (1945) and improved by Kendall (1975), is a rank based non-parametric test for assessing the significance of trends in hydrological and meteorological time series. The $\mathrm{M}-\mathrm{K}$ test for monotonic trend is defined as follows:

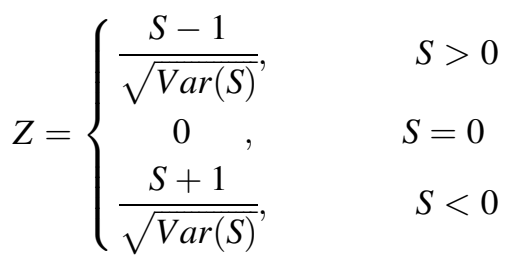

in which

$$
\begin{gathered}
S=\sum_{k=1}^{n-1} \sum_{j=k+1}^{n} \operatorname{sgn}\left(x_{j}-x_{k}\right) \\
\operatorname{var}(S)=\frac{n(n-1)(2 n+5)-\sum_{p=1}^{q} t_{p}\left(t_{p}-1\right)\left(2 t_{p}+5\right)}{18}
\end{gathered}
$$

where $n$ is the length of time series, $x_{j}$ and $x_{k}$ are the sequential data values in periods $j$ and $k(j<k)$, respectively, and $\operatorname{sgn}(\theta)$ is equal to 1,0 and -1 if $\theta$ is greater than, equal to, or less than zero, respectively. $q$ is the number of tied groups, and $t_{p}$ is the number of data values in the $p$ th group. The null hypothesis $H_{0}$ (there is no steep change) is rejected if $|Z|>Z_{(1-\alpha / 2)}$, where $\alpha$ is the significance level for the test, and a significant trend exists in the observed time series. A positive value of $\mathrm{Z}$ indicates an upward trend while a negative value represents a downward trend.

The $\mathrm{M}-\mathrm{K}$ test assumes that the series is independent. However, the presence of serial correlation in the time series can complicate the identification of trends. In this work, the trend-tree pre-whitening method of Yue and Wang (2002) was used to remove the auto-correlation before executing the trend analysis. 
The trend magnitude is estimated using a nonparametric median based slope method proposed by Sen (1968) and extended by Hirsch et al. (1982):

$$
\beta=\operatorname{Median}\left[\frac{x_{j}-x_{k}}{j-k}\right] \quad \text { for all } k<j
$$

where $1<k<j<n$, and $\beta$ is the median of all possible combinations of pairs for the entire data set.

\section{Change-point analysis}

The non-parametric method developed by Pettitt (1979) is widely used to determine the occurrence of a change point (e.g. Xu et al., 2013a, b). This approach detects a significant change in the mean of a time series when the exact time of the change is unknown. The test is a distribution-free method and requires only a few assumptions to be made regarding the data. The test uses a version of the Mann-Whitney statistic $U_{t, N}$ that verifies whether two samples, i.e. $x_{1}, \ldots, x_{t}$ and $x_{t+1}, \ldots, x_{N}$, are from the same population. The test statistic $U_{t, N}$ is given by:

$$
\begin{aligned}
U_{t, N} & =U_{t-1, N}+\sum_{j=1}^{N} \operatorname{sgn}\left(x_{t}-x_{j}\right) \quad \text { for } t \\
& =2, \ldots \ldots \ldots \ldots \ldots, N
\end{aligned}
$$

The test statistic counts the number of times that a member of the first sample exceeds a member of the second sample. The null hypothesis of Pettitt test is the absence of a changing point. Its statistic $k(t)$, and the associated probabilities $(p)$ used in the significance testing are given as follows:

$$
\begin{gathered}
k(t)=\operatorname{Max}_{1 \leq t \leq N}\left|U_{t, N}\right| \\
\text { and } p \cong 2 \exp \left\{-6\left(K_{N}\right)^{2} /\left(N^{3}+N^{2}\right)\right\}
\end{gathered}
$$

\section{Double mass curve method}

The double mass curve is a visual and practical method to identify the hydrological regime changes caused by anthropogenic disturbances (Huo et al., 2008; Gao et al., 2013). The theory is that a plot of the two cumulative quantities exhibits a straight line if the two variables are proportional, and the slope of this line represents the constant of proportionality between the two variables. A break in the slope within a double mass curve indicates that a change in the constant of proportionality occurred. In this study, double mass curves of precipitation versus streamflow and precipitation versus sediment load were plotted. These curves were subsequently used to estimate the relative effects of human activities and climate variability on the annual and flood season streamflow and sediment load changes.
The linear regression equations between the accumulative streamflow-precipitation and sediment loadprecipitation before the transition years were established. The average streamflow and sediment load after the change point without the effects of human activities were extrapolated using the established regression equations and precipitation data post the change point. The difference between the observed and calculated streamflow and sediment load after the breakpoint was considered to represent the cumulative effects of human activities, and the residual changes were attributed to climate variability.

\section{RESULTS}

\section{Changes of catchment climate}

The monotonic trends of annual $P, P E T, A I, T_{\text {mean }}$, $T_{\max }, T_{\min }$ and $H A$ during 1952-2011 over the Yanhe watershed are shown in Figure 2, and the statistical and trend test results of these climate variables are given in Table I. The mean annual $P$ was $504.03 \mathrm{~mm}$, and the maximum annual $P(859.70 \mathrm{~mm}$ in 1964$)$ was approxi-
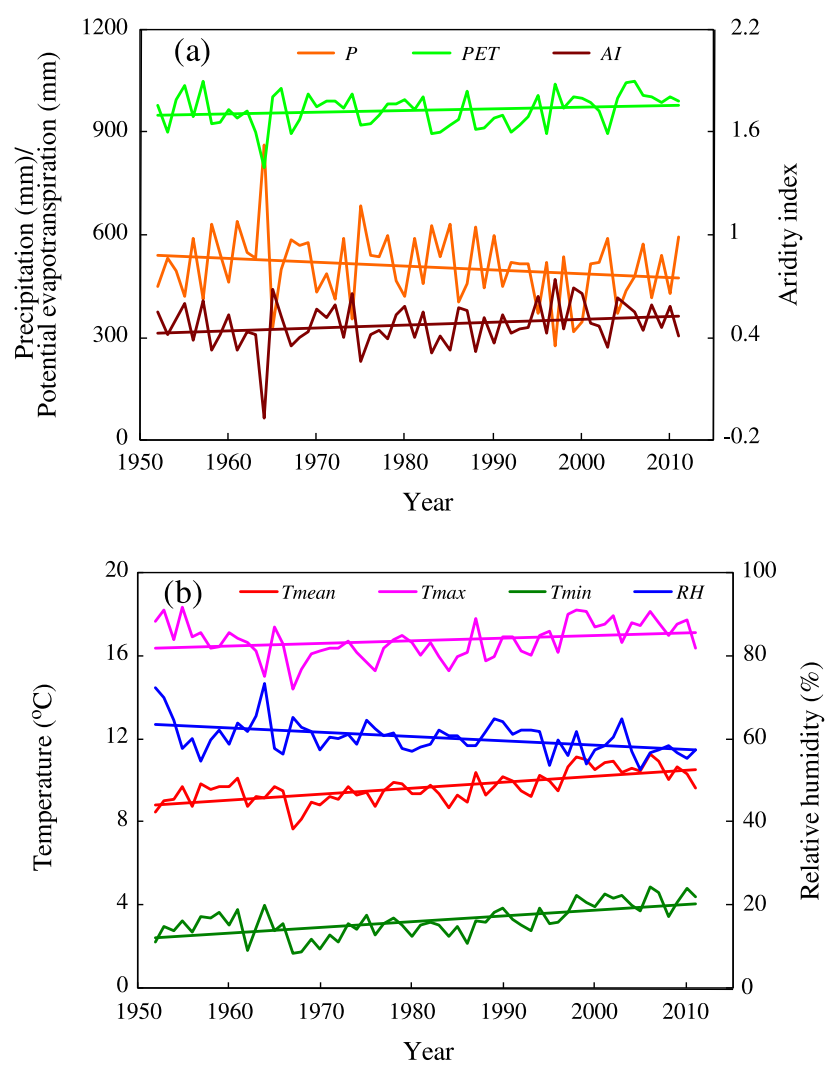

Figure 2. Time series of annual (a) precipitation $(P)$, potential evapotranspiration (PET), aridity index $(A I)$, and (b) temperature $\left(T_{\text {mean }}\right.$, $T_{\max }$, and $\left.T_{\min }\right)$ and relative humidity $(R H)$ of the watershed from 1952 to 2011. The solid line is the linearly fitted trend line for the evolution of the climate variables 
Table I. Statistics and Mann-Kendall trend analysis results of the annual precipitation $(P)$, potential evapotranspiration $(P E T)$, aridity index $(A I)$, temperature $\left(T_{\text {mean }}, T_{\max }\right.$ and $\left.T_{\min }\right)$ and relative humidity $(R H)$ during $1952-2011$

\begin{tabular}{|c|c|c|c|c|c|c|c|c|}
\hline \multirow{2}{*}{$\begin{array}{l}\text { Climate } \\
\text { variable }\end{array}$} & \multirow[b]{2}{*}{ Mean } & \multirow[b]{2}{*}{ Max (year) } & \multirow[b]{2}{*}{ Min (year) } & \multirow[b]{2}{*}{$C_{\mathrm{v}}$} & \multicolumn{4}{|c|}{ Trend test } \\
\hline & & & & & $Z$ & Trend $^{\mathrm{a}}$ & Significance ${ }^{b}$ & Slope $(\beta)$ \\
\hline$P(\mathrm{~mm})$ & 504.03 & 859.70 (1964) & 271.04 (1997) & 0.202 & -1.218 & $\downarrow$ & - & -0.889 \\
\hline PET (mm) & 962.29 & 1045.47 (1957) & 796.12 (1964) & 0.517 & 1.282 & $\uparrow$ & - & 0.478 \\
\hline$A I$ & 0.47 & 0.74 (1997) & $-0.08(1964)$ & 0.278 & 1.563 & $\uparrow$ & - & 0.001 \\
\hline$T_{\text {mean }}\left({ }^{\circ} \mathrm{C}\right)$ & 9.71 & 11.33 (2006) & 7.72 (1967) & 0.078 & 5.160 & $\uparrow$ & $* *$ & 0.028 \\
\hline$T_{\max }\left({ }^{\circ} \mathrm{C}\right)$ & 16.77 & 18.34 (1955) & 14.43 (1967) & 0.051 & 1.856 & $\uparrow$ & - & 0.015 \\
\hline$T_{\min }\left({ }^{\circ} \mathrm{C}\right)$ & 3.29 & $4.86(2006)$ & 1.70 (1967) & 0.237 & 5.058 & $\uparrow$ & $* *$ & 0.029 \\
\hline$R H(\%)$ & 60.50 & 73.34 (1964) & $52.84(2005)$ & 0.067 & -3.272 & $\downarrow$ & ** & -0.090 \\
\hline
\end{tabular}

a ' $\downarrow$ ' indicates a downward trend, ' $\uparrow$ ' indicates an upward trend.

$\mathrm{b}$ ' $* *$ ' and '*' indicate significance levels of 0.01 and 0.05 , respectively, ' - ' indicates that the significance level exceeds 0.05 .

mately three times of the minimum value $(271.04 \mathrm{~mm}$ in 1997). The mean annual PET (962.29) was approximately two times as large as the mean annual $P$. Accordingly, the $A I$ exhibited an average value of 0.47 . The driest and wettest years were 1997 and 1964, corresponding to the $A I$ values of 0.74 and -0.08 , respectively. The mean values of the annual $T_{\text {mean }}, T_{\max }$ and $T_{\min }$ were 9.71 , 16.77 and $3.29^{\circ} \mathrm{C}$, respectively. The differences between the maximum and minimum values of $T_{\text {mean }}, T_{\max }$ and $T_{\min }$ were $3.61,3.91$ and $3.16^{\circ} \mathrm{C}$, respectively. The annual $R H$ had a mean value of $60.50 \%$ with the maximum and minimum values of $75.34 \%$ in 1964 and $52.38 \%$ in 2005 , respectively. The PET exhibited the largest variability with the $C_{\mathrm{v}}$ value of 0.517 , and the $T_{\max }$ was most stable indicated by the smallest $C_{\mathrm{v}}$ value (0.051) among the climate variables.

The annual $P$ exhibited a negative trend with a reduction of 0.889 mm year $^{-1}$ over the past 60 years, whereas the annual $P E T$ and $A I$ had increasing trends of $0.478 \mathrm{~mm}$ year $^{-1}$ and 0.001 year $^{-1}$, respectively. However, the trends of $P, P E T$ and $A I$ were not significant (Table I). All the three annual air temperature variables exhibited positive trends with increasing rate of $0.028,0.015$ and

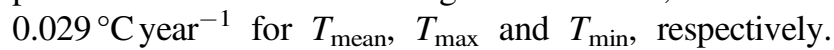
However, only $T_{\text {mean }}$ and $T_{\text {min }}$ had significant trends $(p<0.01)$, and the trend in $T_{\max }$ was not significant. A significant decreasing trend $(p<0.01)$ with a changing rate of $0.09 \%$ year $^{-1}$ was observed for $R H$.

The average values of the flood season $P, P E T$ and $A I$ were $359.65 \mathrm{~mm}, 482.83 \mathrm{~mm}$ and 0.25 , accounting on average for $71.35 \%, 50.17 \%$ and $53.19 \%$ of the annual values, respectively. Furthermore, the flood season $P$, $P E T$ and $A I$ exhibited the same changing trends as the annual scale. However, the changing rates of flood season $P\left(-0.717 \mathrm{~mm} \mathrm{year}^{-1}\right)$ and PET $\left(0.224 \mathrm{~mm} \mathrm{year}^{-1}\right)$ were smaller than those of annual values, whereas the flood season $A I$ exhibited a greater increasing trend $\left(0.002\right.$ years $\left.^{-1}\right)$ than annual $A I$.
The average values of the monthly $P, P E T$ and $A I$ from 1952 to 2011 are shown in Figure 3. The monthly $P, P E T$ and $A I$ showed somewhat different seasonal cycles, especially with respect to the month in which the maximum value occurred. The monthly $P$ reached the maximum in July and August at 110.74 and $111.65 \mathrm{~mm}$, respectively. Moreover, the monthly PET was greater than $100 \mathrm{~mm}$ during April-August, exhibiting its highest value in June $(146.64 \mathrm{~mm})$. The watershed was wettest in August and September as indicated by the lowest values of the $A I$ (0.044 and 0.036, respectively), and the driest season was during December-February in which the $A I$ exceeded 0.80 . The $\mathrm{M}-\mathrm{K}$ trend test results in Figure 4 indicated that the monthly $P$ exhibited an increasing trend only in January, February and June. In contrast, the monthly $A I$ had a decreasing trend in these three months. The monthly PET exhibited a positive trend in most of months except in January, June and December. However, the trend of $P, P E T$ and $A I$ in each month was not significant (Figure 4).

\section{Changes of streamflow and sediment load}

Changes on annual and flood season scales. The statistics of the annual and flood season $R, S, S C, C_{\mathrm{r}}$ and $C_{\mathrm{s}}$ during

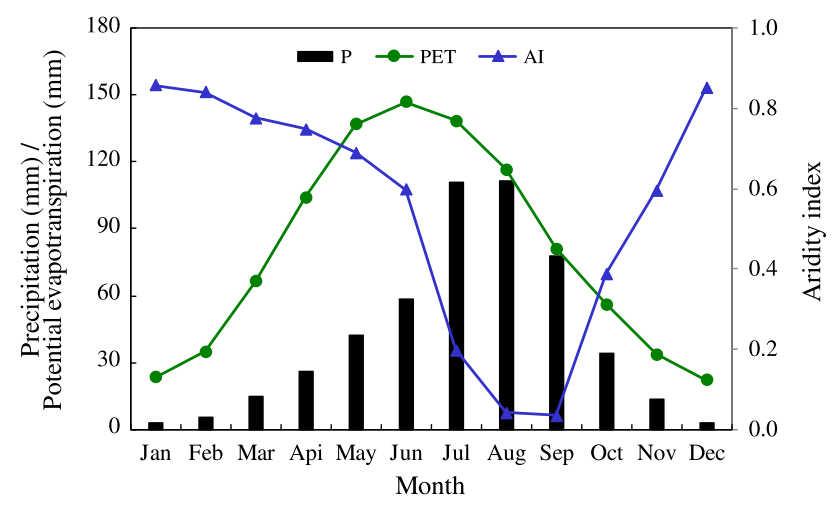

Figure 3. Average monthly precipitation $(P)$, potential evapotranspiration (PET), aridity index $(A I)$ in the watershed from 1952 to 2011 


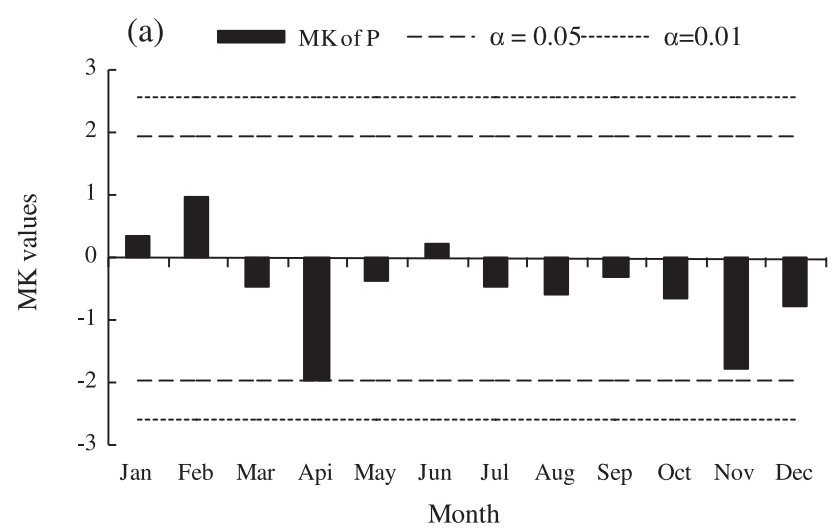

(b) MK of PET - - $\cdot \alpha=0.05 \cdots \cdots=0.01$

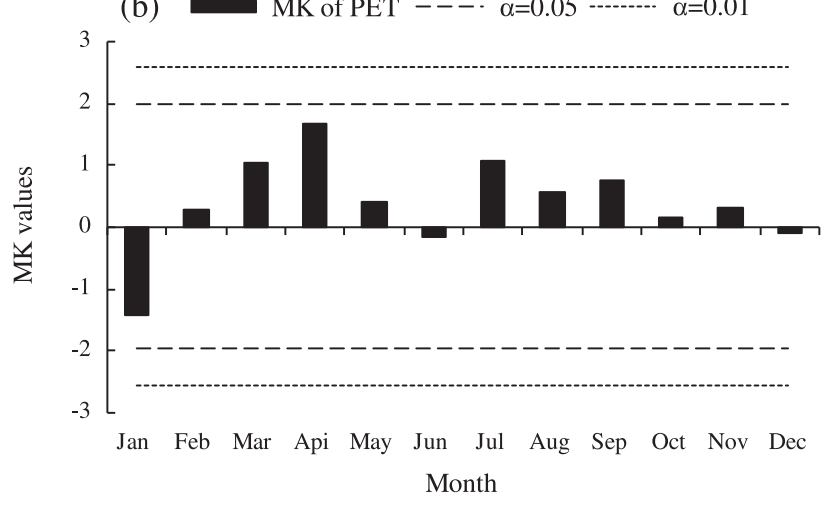

(c) MK of AI - - $-\alpha=0.05 \quad \cdots-\cdots \cdot \alpha=0.01$

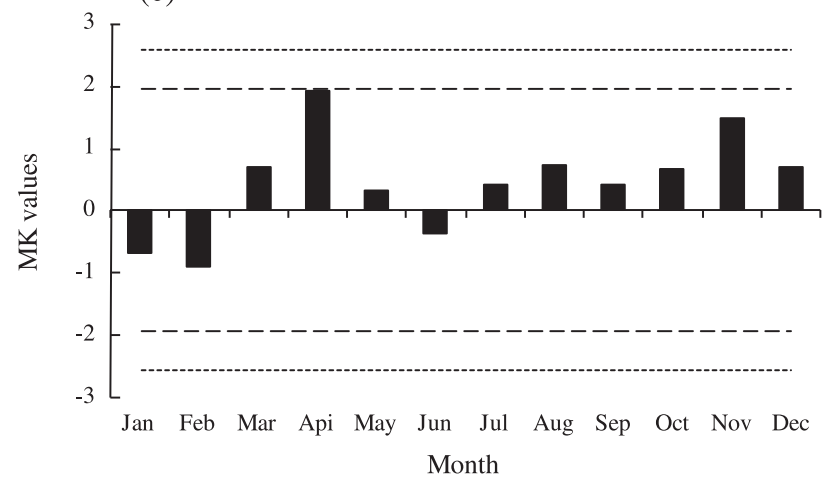

Figure 4. Mann-Kendall trend test results of the monthly (a) precipitation $(P),(b)$ potential evapotranspiration $(P E T)$, and (c) aridity index $(A I)$ in the watershed from 1952 to 2011
1952-2011 are shown in Table II. The mean streamflow in the flood season $\left(1.28 \times 10^{8} \mathrm{~m}^{3}\right)$ accounted for more than $60 \%$ of the annual total $\left(2.02 \times 10^{8} \mathrm{~m}^{3}\right)$. Moreover, nearly all $(98.6 \%)$ of the sediment load for the entire year $\left(4070.01 \times 10^{4} \mathrm{t}\right)$ occurred in the flood season $\left(4012.23 \times 10^{4} \mathrm{t}\right)$. The mean flood season $S C$ $\left(269.19 \mathrm{~kg} \mathrm{~m}^{-3}\right)$ was approximately one and a half times of the annual value $\left(175.13 \mathrm{~kg} \mathrm{~m}^{-3}\right)$. The ratio between the mean flood season and annual $C_{\mathrm{r}}(5.90 \% / 6.76 \%)$ was 0.873 , indicating that the runoff availability per unit precipitation in the flood season was smaller than that over the entire year. In contrast, the mean flood season $C_{\mathrm{s}}$ value $\left(18.14 \mathrm{t} \mathrm{km}^{-2} \mathrm{~mm}^{-1}\right)$ was much larger than the annual value $\left(13.23 \mathrm{t} \mathrm{km}^{-2} \mathrm{~mm}^{-1}\right)$.

Although there were significant differences between the annual and flood season runoff and sediment values, the extrema of the annual and flood season hydrological variables primarily occurred in the same years (Table II). The maximum annual and flood season $R, S$ and $S C$ values occurred in 1964 or 1966, while the maximum $C_{\mathrm{r}}$ and $C_{\mathrm{s}}$ values occurred in 1977. The minimum value of these five hydrological variables occurred recently (2008 or 2011). The maximum $R$ and $C_{\mathrm{r}}$ was approximately several times larger than the minimum value, whereas the differences between the maximum and minimum values of $S, S C$ and $C_{\mathrm{s}}$ were approximately two orders of magnitude larger than those of $R$ and $C_{\mathrm{r}}$ (Table II). Furthermore, the $S, S C$ and $C_{\mathrm{s}}$ exhibited greater variability than $R$ and $C_{\mathrm{r}}$ accordingly to a comparison of their $C_{\mathrm{v}}$ values (Table II).

The evolution of the annual and flood season $R, S, S C$, $C_{\mathrm{r}}$ and $C_{\mathrm{s}}$ from 1952 to 2011 is shown in Figure 5. A linear regression analysis suggested that all these five hydrological variables witnessed a decreasing trend over the past 60 years. The largest decrease occurred after 2005 (Figure 5). The M-K trend test results in Tables III and IV indicated that the decreasing trends of $R, S, S C$ and $C_{\mathrm{s}}$ on both annual and flood season scales were significant $(p<0.01)$. A significant negative trend $(p<0.01)$ was detected for the flood season $C_{\mathrm{r}}$ (Table IV), whereas the annual $C_{\mathrm{r}}$ did not have a significant decreasing trend

Table II. Statistics of the annual and flood season streamflow $(R)$, sediment load $(S)$, sediment concentration $(S C)$, runoff coefficient $\left(C_{\mathrm{r}}\right)$ and sediment coefficient $\left(C_{\mathrm{s}}\right)$ during 1952-2011

\begin{tabular}{|c|c|c|c|c|c|c|c|c|c|}
\hline \multirow{2}{*}{$\begin{array}{l}\text { Hydrological } \\
\text { variable }\end{array}$} & \multicolumn{4}{|c|}{ Annual } & \multicolumn{4}{|c|}{ Flood season } & \multirow{2}{*}{ Ratio of means } \\
\hline & Mean & Max (year) & Min (year) & $C_{\mathrm{v}}$ & Mean & Max (year) & Min (year) & $C_{\mathrm{v}}$ & \\
\hline$R\left(10^{8} \mathrm{~m}^{3}\right)$ & 2.02 & $5.02(1964)$ & $1.06(2008)$ & 0.369 & 1.28 & 3.81 (1964) & $0.36(2008)$ & 0.537 & 0.634 \\
\hline$S\left(10^{4} \mathrm{t}\right)$ & 4070.01 & 18171.93 (1964) & $82.17(2011)$ & 0.863 & 4012.23 & $18136.14(1964)$ & $67.84(2011)$ & 0.874 & 0.986 \\
\hline$S C\left(\mathrm{~kg} \mathrm{~m}^{-3}\right)$ & 175.13 & $383.61(1966)$ & $7.04(2011)$ & 0.541 & 269.19 & 493.77 (1966) & $12.58(2011)$ & 0.434 & 1.537 \\
\hline$C_{\mathrm{r}}(\%)$ & 6.76 & 12.07 (1977) & $3.35(2011)$ & 0.260 & 5.90 & $12.58(1977)$ & $1.84(2008)$ & 0.387 & 0.873 \\
\hline$C_{\mathrm{s}}\left(\mathrm{t} \mathrm{km}^{-2} \mathrm{~mm}^{-1}\right)$ & 13.23 & 44.66 (1977) & $0.24(2011)$ & 0.739 & 18.14 & 57.64 (1977) & $0.31(2011)$ & 0.716 & 1.371 \\
\hline
\end{tabular}



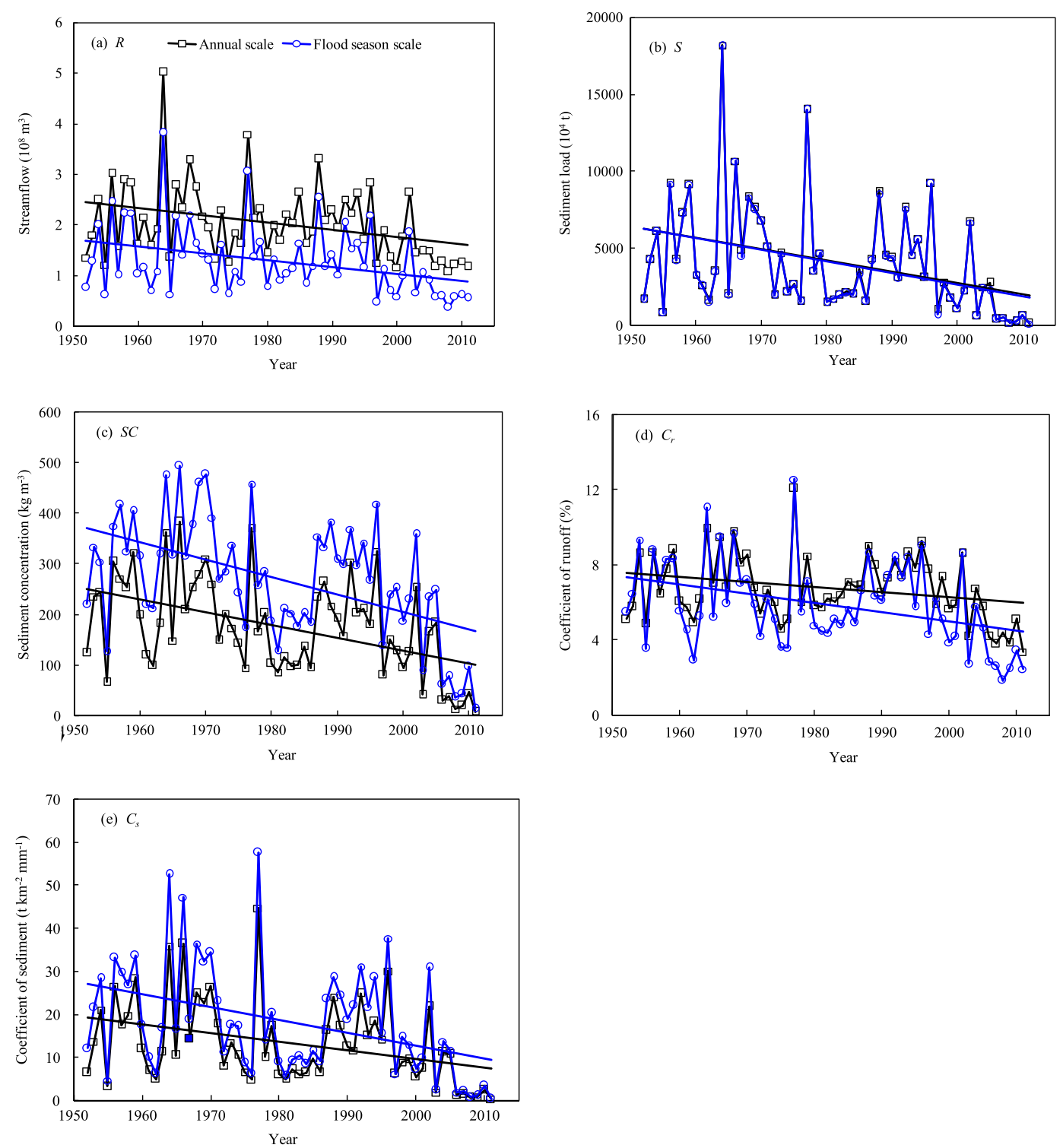

Figure 5. Time series of annual and flood season (a) streamflow $(R)$, (b) sediment load $(S)$, (c) sediment concentration $(S C)$, (d) runoff coefficient $\left(C_{\mathrm{r}}\right)$, and (e) sediment coefficient $\left(C_{\mathrm{s}}\right)$ of the watershed from 1952 to 2011 . The solid line is the linearly fitted trend line for the evolution of the hydrological variables

Table III. Mann-Kendall trend test and Pettitt change point analysis results of the annual streamflow $(R)$, sediment load $(S)$, sediment concentration $(S C)$, runoff coefficient $\left(C_{\mathrm{r}}\right)$ and sediment coefficient $\left(C_{\mathrm{s}}\right)$ during 1952-2011

\begin{tabular}{|c|c|c|c|c|c|c|c|c|c|}
\hline \multirow{2}{*}{$\begin{array}{l}\text { Annual } \\
\text { hydrological } \\
\text { variable }\end{array}$} & \multicolumn{4}{|c|}{ Trend test } & \multicolumn{5}{|c|}{ Change point analysis } \\
\hline & Z & Trend & Significance & Slope $(\beta)$ & Year & $p$ & Pre-T ${ }^{a}$ & Post-T ${ }^{b}$ & Change $^{\mathrm{c}}(\%)$ \\
\hline$R\left(10^{8} \mathrm{~m}^{3}\right)$ & -2.768 & $\downarrow$ & $* *$ & -0.014 & 1996 & 0.003 & 2.21 & 1.44 & -34.84 \\
\hline$S\left(10^{4} t\right)$ & -3.387 & $\downarrow$ & $* *$ & -62.628 & 1996 & 0.004 & 4912.79 & 1541.68 & -68.61 \\
\hline$S C\left(\mathrm{~kg} \mathrm{~m}^{-3}\right)$ & -3.629 & $\downarrow$ & $* *$ & -2.763 & 1996 & 0.006 & 203.02 & 91.46 & -54.95 \\
\hline$C_{\mathrm{r}}(\%)$ & -1.716 & $\downarrow$ & - & -0.024 & 1999 & 0.025 & 7.17 & 5.12 & -28.59 \\
\hline$C_{\mathrm{s}}\left(\mathrm{t} \mathrm{km}^{-2} \mathrm{~mm}^{-1}\right)$ & -3.157 & $\downarrow$ & ** & -0.199 & 1996 & 0.009 & 15.66 & 5.94 & -62.06 \\
\hline
\end{tabular}

' $\downarrow$ ' indicates a downward trend; ' $\uparrow$ ' indicates an upward trend.

'**' and '*' indicate significance levels of 0.01 and 0.05 , respectively; ' - ' indicates that the significance level exceeds 0.05 .

${ }^{a}$ Mean value before the change point.

${ }^{\mathrm{b}}$ Mean value after the change point.

${ }^{\mathrm{c}}$ Change of the mean value between pre-T and post-T. 
Table IV. Mann-Kendall trend test and Pettitt change point analysis results of the flood season streamflow $(R)$, sediment load $(S)$, sediment concentration $(S C)$, runoff coefficient $\left(C_{\mathrm{r}}\right)$ and sediment coefficient $\left(C_{\mathrm{s}}\right)$ during 1952-2011

\begin{tabular}{|c|c|c|c|c|c|c|c|c|c|}
\hline \multirow{2}{*}{$\begin{array}{l}\text { Flood season } \\
\text { hydrological } \\
\text { variable }\end{array}$} & \multicolumn{4}{|c|}{ Trend test } & \multicolumn{5}{|c|}{ Change point analysis } \\
\hline & $Z$ & Trend & Significance & Slope $(\beta)$ & Year & $p$ & Pre-T & Post-T & Change \\
\hline$R\left(10^{8} \mathrm{~m}^{3}\right)$ & -2.991 & $\downarrow$ & $* *$ & -0.012 & 1996 & 0.002 & 1.45 & 0.76 & $-47.58 \%$ \\
\hline$S\left(10^{4} \mathrm{t}\right)$ & -3.387 & $\downarrow$ & $* *$ & -61.910 & 1996 & 0.003 & 4860.19 & 1468.37 & $-69.78 \%$ \\
\hline$S C\left(\mathrm{~kg} \mathrm{~m}^{-3}\right)$ & -3.859 & $\downarrow$ & $* *$ & -3.768 & 1996 & 0.005 & 307.73 & 153.55 & $-50.10 \%$ \\
\hline$C_{\mathrm{r}}(\%)$ & -2.915 & $\downarrow$ & $* *$ & -0.051 & 1996 & 0.009 & 6.52 & 4.07 & $-37.57 \%$ \\
\hline$C_{\mathrm{s}}\left(\mathrm{t} \mathrm{km}^{-2} \mathrm{~mm}^{-1}\right)$ & -3.374 & $\downarrow$ & $* *$ & -0.308 & 1996 & 0.006 & 21.60 & 7.87 & $-63.56 \%$ \\
\hline
\end{tabular}

' $\downarrow$ ' indicates a downward trend; ' $\uparrow$ ' indicates an upward trend.

'**' and ' $*$ ' indicate significance levels of 0.01 and 0.05 , respectively; '-' indicates that the significance level exceeds 0.05 .

(Table III). The annual and flood season $R$ and $S$ had nearly the same decreasing rate, which was approximately $0.01 \times 10^{8} \mathrm{~m}^{3}$ years $^{-1}$ and $60 \times 10^{4}$ tyear $^{-1}$, respectively. However, the $S C, C_{\mathrm{r}}$ and $C_{\mathrm{s}}$ decreased more rapidly in the flood season as the changing rates of annual $S C$ $\left(-2.76 \mathrm{~kg} \mathrm{~m}^{-3}\right.$ years $\left.^{-1}\right), C_{\mathrm{r}}\left(-0.02 \%\right.$ year $\left.^{-1}\right)$ and $C_{\mathrm{s}}$ $\left(-0.20 \mathrm{t} \mathrm{km}^{-2} \mathrm{~mm}^{-1}\right.$ year $\left.{ }^{-1}\right)$ were much smaller than those in the flood season $\left(-3.77 \mathrm{~kg} \mathrm{~m}^{-3}\right.$ years $^{-1}$, $-0.05 \%$ year $^{-1},-0.30 \mathrm{t} \mathrm{km}^{-2} \mathrm{~mm}^{-1}$ year $^{-1}$ for $S C, C_{\mathrm{r}}$ and $C_{\mathrm{s}}$, respectively).

According to the Pettitt test results in Tables III and IV, the annual and flood season hydrological variables had nearly the same change points (1996) except for the abrupt change in the annual $C_{\mathrm{r}}$ that occurred in 1999. All of the abrupt change points were statistically significant $(p<0.05)$. The mean values of the annual $R$ and $C_{\mathrm{r}}$ after the change point decreased by $34.84 \%$ and $28.59 \%$, respectively, which were smaller than the reductions in flood season $(47.85 \%$ and $37.57 \%)$. However, the reductions of $S, S C$ and $C_{\mathrm{s}}$ were nearly identical on the annual and flood season scales, i.e. approximately $70 \%$, $50 \%$ and $60 \%$, respectively. Clearly, the $S, S C$ and $C_{\text {s }}$ exhibited larger reductions after the change point compared to $R$ and $C_{\mathrm{r}}$.

Changes on monthly scale. Figure 6 shows the monthly distribution of $R, S, S C, C_{\mathrm{r}}$ and $C_{\mathrm{s}}$, demonstrating that the $R, S, S C$ and $C_{\mathrm{s}}$ were all concentrated in the rainy season (between May and October) and that the maxima occurred in July and August. Moreover, the $R$ and $S$ during July-August accounted for $46.7 \%$ and $86.2 \%$ of the annual total and $73.6 \%$ and $87.4 \%$ of the flood season total, respectively. The average $S C\left(373.14 \mathrm{~kg} \mathrm{~m}^{-3}\right)$ and $C_{\mathrm{s}}\left(26.79 \mathrm{tkm}^{-2} \mathrm{~mm}^{-1}\right)$ during July-August were approximately two times of the mean annual values and one and a half times of the flood season values. In contrast to the seasonal cycle of $R, S, S C$ and $C_{\mathrm{s}}$, the mean $C_{\mathrm{r}}$ during April-November (6.22\%) was much smaller compared with the other four months (22.83\%) (Figure 6B), which was due to the relatively large baseflow component
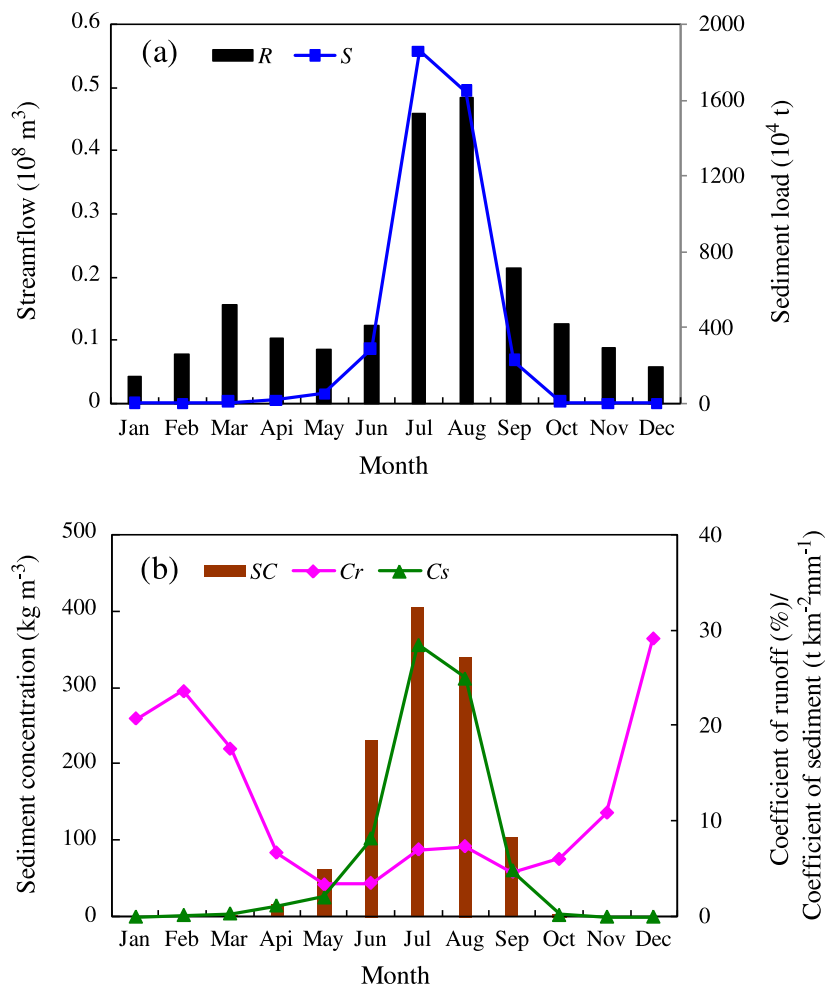

Figure 6. Average monthly (a) streamflow $(R)$ and sediment load $(S)$, and (b) sediment concentration $(S C)$, runoff coefficient $\left(C_{\mathrm{r}}\right)$, and sediment coefficient $\left(C_{\mathrm{s}}\right)$ of the watershed from 1952 to 2011

during December-March from the contribution of snowmelt events. Therefore, the sediment load primarily occurred in summer (June-August), whereas the streamflow in spring (March-May) and winter (December-February) also contributed to the annual value.

The M-K trend test results of $R, S, S C, C_{\mathrm{r}}$ and $C_{\mathrm{s}}$ during May-October are shown in Figure 7. Although the annual $R$ and $C_{\mathrm{r}}$ exhibited decreasing trends, positive trends were detected for both $R$ and $C_{\mathrm{r}}$ in May (not significant). The decreasing trends of $R$ and $C_{\mathrm{r}}$ during June-October were only significant in July $(p<0.05)$ and August $(p<0.01)$ (Figure 7A and D). Therefore, the decreasing of annual and 

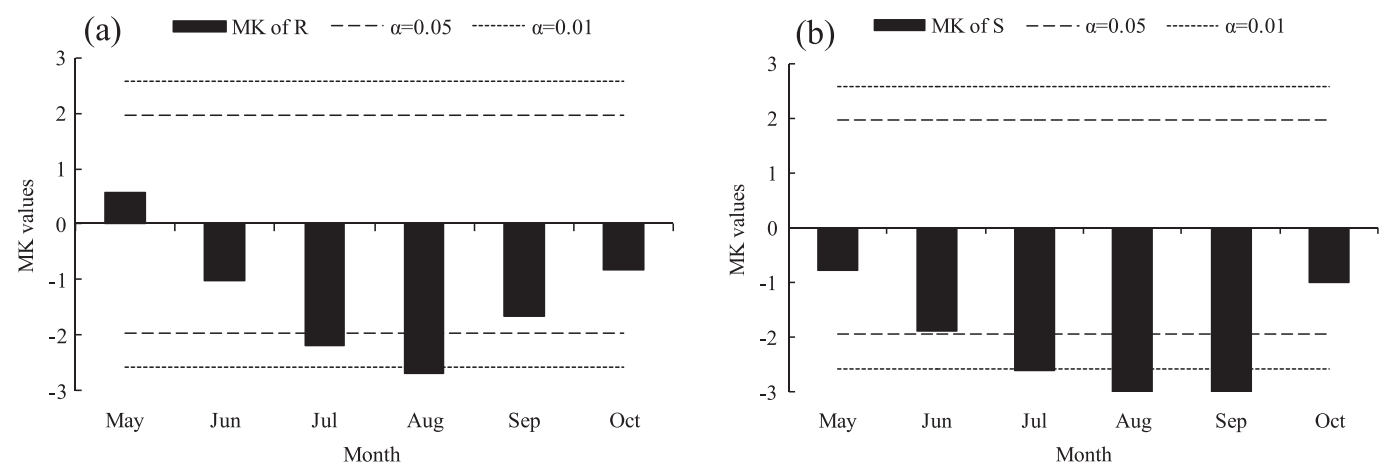

(c) $\quad$ MK of SC $---\alpha=0.05 \quad \cdots \cdots \cdots \cdots, \alpha=0.01$

(d)

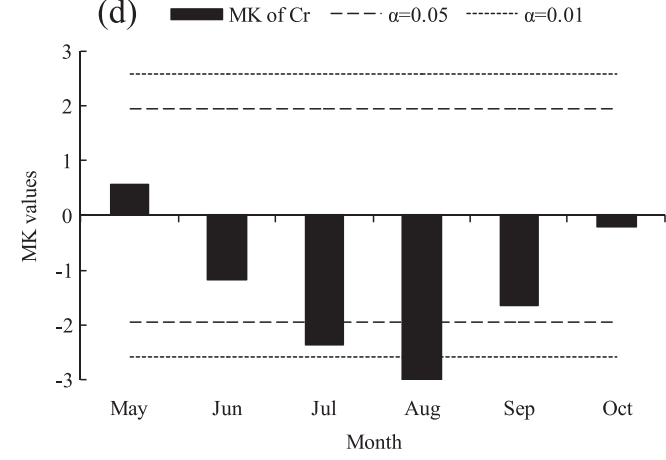

(e) $\quad$ MK of Cs $---\cdot \alpha=0.05 \quad \cdots-\cdots-\cdots=0.01$

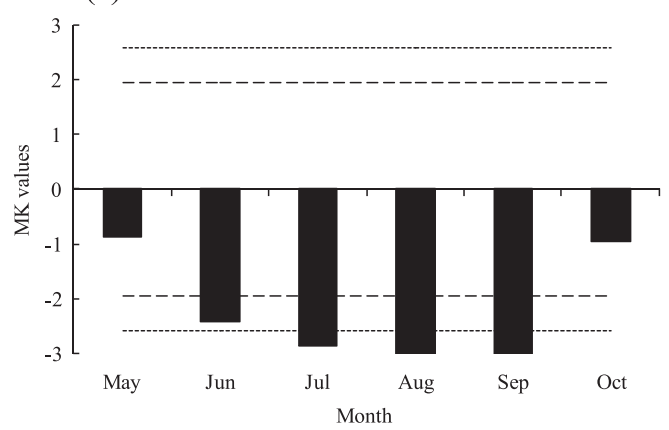

Figure 7. Mann-Kendall trend test results of the monthly (a) streamflow $(R)$, (b) sediment load (S), (c) sediment concentration (SC), (d) runoff coefficient $\left(C_{\mathrm{r}}\right)$, and (e) sediment coefficient $\left(C_{\mathrm{s}}\right)$ of the watershed from 1952 to 2011

flood season streamflow was mainly caused by the decline in July and August. The monthly $S, S C$ and $C_{\mathrm{s}}$ exhibited decreasing trends in every month during May-October, and the trends were significant at the 5\% level in June and at the $1 \%$ level from July to September. Moreover, the $R, S, S C, C_{\mathrm{r}}$ and $C_{\mathrm{s}}$ all decreased most rapidly in July-August, and the corresponding changing rates were $-0.005 \times 10^{8} \mathrm{~m}^{3}$ years $^{-1}, \quad-22.278 \times 10^{4}$ t year $^{-1}$, $-3.836 \mathrm{~kg} \mathrm{~m}^{-3}$ years $^{-1}, \quad-0.066 \%$ year $^{-1}$ and $-0.388 \mathrm{t} \mathrm{km}^{-2} \mathrm{~mm}^{-1}$ year $^{-1}$, respectively. Therefore, substantial changes occurred in July-August compared with the other months.

Changes on daily scale. The inter-annual variations of $Q_{\mathrm{md}}, P_{\mathrm{Rmd}}, Q_{\mathrm{smd}}, P_{\mathrm{Smd}}$ and $S C_{\mathrm{md}}$ during 1952 and 2011 are shown in Figure 8, and the statistics of these five maximum daily hydrological variables were given in Table V. The $Q_{\mathrm{md}}$ ranged from $1500 \mathrm{~m}^{3} \mathrm{~s}^{-1}$ (in 1977) to $24.9 \mathrm{~m}^{3} \mathrm{~s}^{-1}$ (in 2008) with an average of $248.18 \mathrm{~m}^{3} \mathrm{~s}^{-1}$. The corresponding $R_{\mathrm{md}}$ (maximum daily streamflow) accounted for $9.7 \%$ of the annual total streamflow on average, even reaching approximately one third in 1977. Compared with $Q_{\mathrm{md}}$, the $Q_{\text {smd }}$ exhibited much more interannual variability with the $C_{\mathrm{v}}$ value of 1.155 . The maximum $Q_{\text {smd }}$ in $1977\left(1090.50 \mathrm{ts}^{-1}\right)$ was nearly 1000 times larger than the minimum value in $2011\left(1.65 \mathrm{t} \mathrm{s}^{-1}\right)$. Furthermore, the $S_{\mathrm{md}}$ (maximum daily sediment load) accounted for an average of approximately $30 \%$ of the annual sediment load. The maximum percentage was $67.31 \%$ in 1977 , while the minimum percentage was 

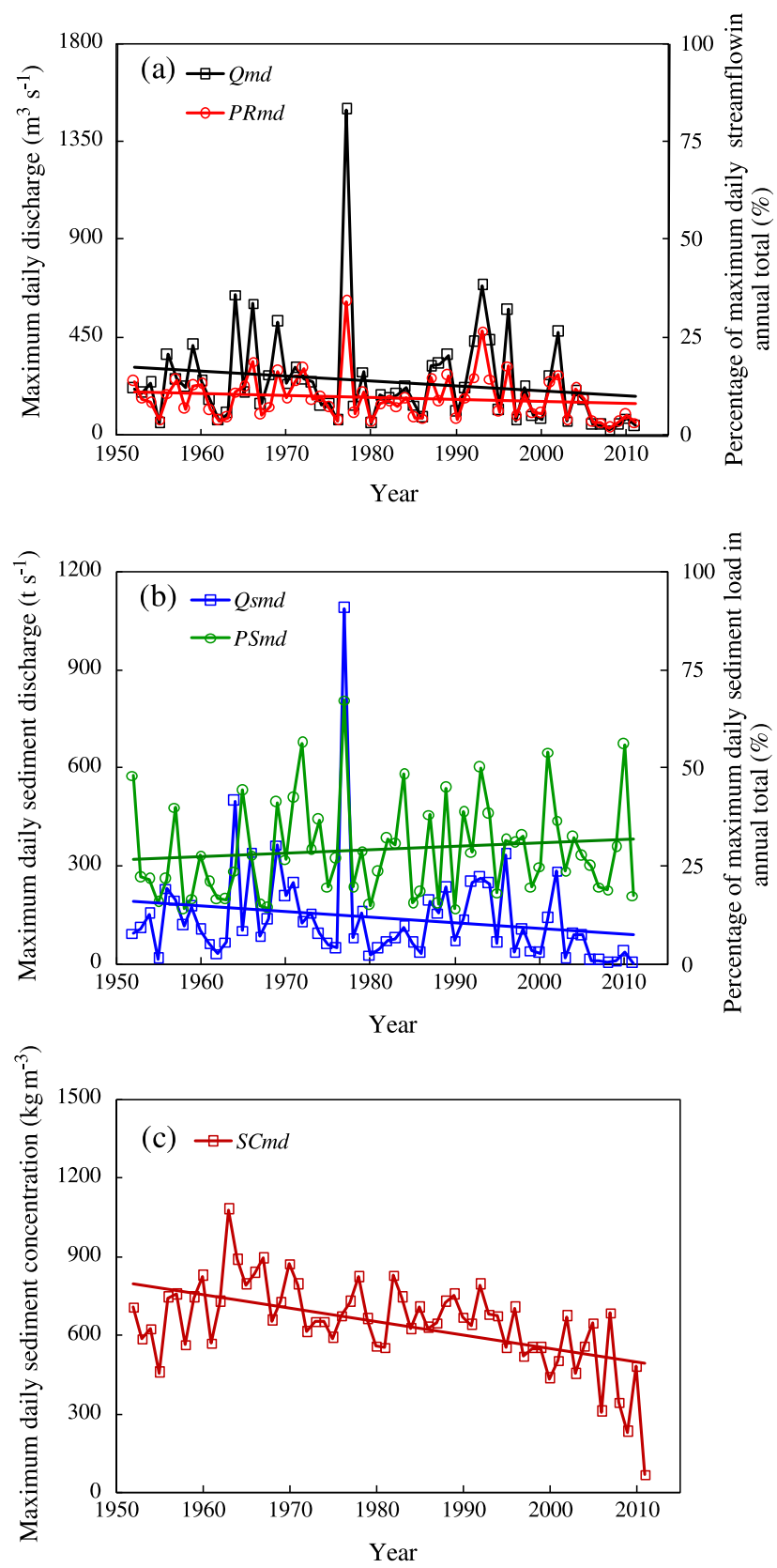

Figure 8 . Time series of (a) the maximum daily discharge $\left(Q_{\mathrm{md}}\right)$ and percentage of the maximum daily streamflow contributing to the annual total $\left(P_{\mathrm{Rmd}}\right)$, (b) the maximum daily sediment discharge $\left(Q_{\mathrm{smd}}\right)$ and percentage of the maximum daily sediment load contributing to annual total $\left(P_{\mathrm{Smd}}\right)$, and $(\mathrm{c})$ the maximum daily discharge sediment concentration $\left(S C_{\mathrm{md}}\right)$ in each year of the watershed from 1952 to 2011 . The solid line is the linearly fitted trend line for the evolution of the hydrological variables

$13.93 \%$ in 1958 . The maximum $Q_{\mathrm{md}}, P_{\mathrm{Rmd}}, Q_{\mathrm{smd}}$ and $P_{\text {Smd }}$ all occurred in 1977 as a result of the catastrophic rainstorm and flood from July 5 to 6 of 1977. Events of this magnitude were rare over the recent one and two hundred years. Furthermore, the $S C_{\mathrm{md}}$ ranged from $1080 \mathrm{~kg} \mathrm{~m}^{-3}$ (in 1963) to $65.20 \mathrm{~kg} \mathrm{~m}^{-3}$ (in 2011), exhibiting a mean of $645.07 \mathrm{~kg} \mathrm{~m}^{-3}$, which was 3.68
Table V. Statistics of the maximum daily hydrological variables in each year $\left(Q_{\mathrm{md}}, P_{\mathrm{Rmd}}, Q_{\mathrm{smd}}, P_{\mathrm{Smd}}\right.$ and $\left.S C_{\mathrm{md}}\right)$ during $1952-$ 2011

\begin{tabular}{lrrrr}
\hline $\begin{array}{l}\text { Maximum daily } \\
\text { hydrological } \\
\text { variable }\end{array}$ & Mean & Max (year) & Min (year) & $C_{\mathrm{v}}$ \\
\hline$Q_{\mathrm{md}}\left(\mathrm{m}^{3} \mathrm{~s}^{-1}\right)$ & 248.18 & $1500.00(1977)$ & $24.90(2008)$ & 0.926 \\
$P_{\mathrm{Rmd}}(\%)$ & 9.70 & $34.25(1977)$ & $2.03(2008)$ & 0.612 \\
$Q_{\text {smd }}\left(\mathrm{t} \mathrm{s}^{-1}\right)$ & 140.04 & $1090.50(1977)$ & $1.65(2011)$ & 1.155 \\
$P_{\text {Smd }}(\%)$ & 29.15 & $67.31(1977)$ & $13.93(1958)$ & 0.433 \\
$S C_{\text {md }}\left(\mathrm{kg} \mathrm{m}^{-3}\right)$ & 645.07 & $1080.00(1963)$ & $65.20(2011)$ & 0.258
\end{tabular}

Notes: ${ }^{a} Q_{\mathrm{md}}, Q_{\mathrm{smd}}$ and $S C_{\mathrm{md}}$ indicate the maximum daily discharge, sediment discharge and sediment concentration during one year, respectively. $P_{\mathrm{Rmd}}$ and $P_{\mathrm{Smd}}$ indicate the percentage of the maximum daily streamflow and sediment load contributing to the annual total, respectively.

and 2.40 times larger than the annual and flood season $S C$ $\left(175.13 \mathrm{~kg} \mathrm{~m}^{-3}\right.$ and $\left.269.19 \mathrm{~kg} \mathrm{~m}^{-3}\right)$, respectively. The aforementioned results indicated that the streamflow and sediment resulting from the extreme flood event had substantial contributions to the annual totals in the watershed.

Figure 9 shows the occurrence date distribution of $Q_{\mathrm{md}}$, $Q_{\text {smd }}$ and $S C_{\mathrm{md}}$. Most of $Q_{\mathrm{md}}, Q_{\mathrm{smd}}$ and $S C_{\mathrm{md}}$ occurred in July and August during the last 60 years. The median occurrence dates of $Q_{\mathrm{md}}, Q_{\mathrm{smd}}$ and $S C_{\mathrm{md}}$ were July 31 , July 30 and July 19 , respectively. The occurrence dates of $Q_{\mathrm{md}}$ and $Q_{\text {smd }}$ were nearly same, which lagged behind that of $S C_{\mathrm{md}}$ (Figure 9).

As shown in Figure 8A, the $Q_{\mathrm{md}}$ and $P_{\mathrm{Rmd}}$ represented decreasing trends over the last 60 years. The $\mathrm{M}-\mathrm{K}$ trend test results indicated that the decreasing trend of $Q_{\mathrm{md}}$ $\left(-2.548 \mathrm{~m}^{3} \mathrm{~s}^{-1}\right.$ year $\left.^{-1}\right)$ was significant $(p<0.05)$, whereas the changing of $P_{\mathrm{Rmd}}\left(-0.065 \%\right.$ year $\left.^{-1}\right)$ was not significant (Table VI). Furthermore, the $Q_{\text {smd }}$ decreased

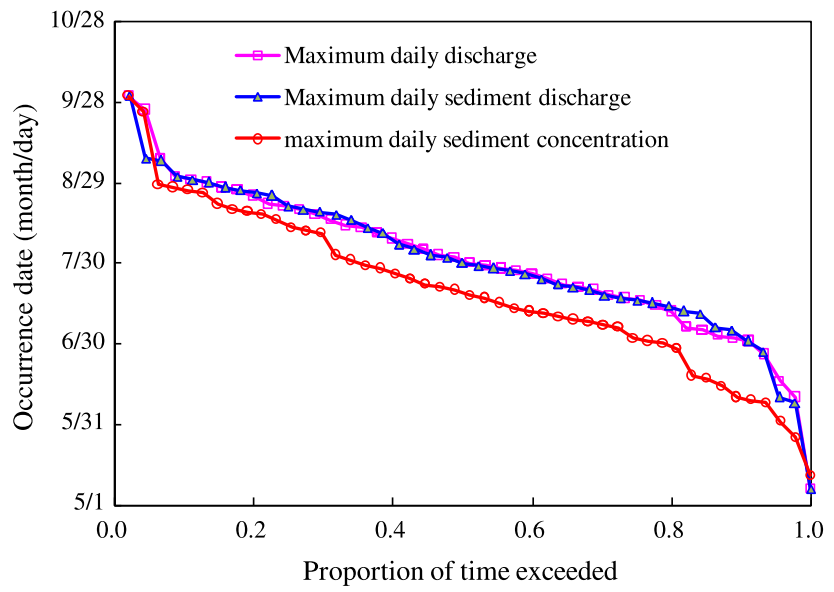

Figure 9. Occurrence date distribution of the maximum daily discharge $\left(Q_{\mathrm{md}}\right)$, sediment discharge $\left(Q_{\mathrm{smd}}\right)$ and sediment concentration $\left(S C_{\mathrm{md}}\right)$ from 1952 to 2011 
Table VI. Mann-Kendall trend test and Pettitt change point analysis results of maximum daily hydrological variables in each year $\left(Q_{\mathrm{md}}\right.$, $P_{\mathrm{Rmd}}, Q_{\mathrm{smd}}, P_{\mathrm{Smd}}$ and $\left.S C_{\mathrm{md}}\right)$ during 1952-2011

\begin{tabular}{|c|c|c|c|c|c|c|c|c|c|}
\hline \multirow{2}{*}{$\begin{array}{l}\text { Maximum } \\
\text { daily } \\
\text { hydrological } \\
\text { variable }\end{array}$} & \multicolumn{4}{|c|}{ Trend test } & \multicolumn{5}{|c|}{ Change point analysis } \\
\hline & $Z$ & Trend & Significance & Slope $(\beta)$ & Year & $P$ & Pre- $\mathrm{T}$ & Post-T & Change \\
\hline$Q_{\mathrm{md}}\left(\mathrm{m}^{3} \mathrm{~s}^{-1}\right)$ & -2.405 & $\downarrow$ & $*$ & -2.548 & 1996 & 0.027 & 287.85 & 129.16 & $-55.12 \%$ \\
\hline$P_{\text {Rmd }}(\%)$ & -1.843 & $\downarrow$ & - & -0.065 & 2002 & 0.128 & 10.50 & 5.12 & $-51.23 \%$ \\
\hline$Q_{\text {smd }}\left(\mathrm{ts}^{-1}\right)$ & -2.570 & $\downarrow$ & $*$ & -1493.336 & 1996 & 0.022 & 166.74 & 59.94 & $-64.05 \%$ \\
\hline$P_{\text {Smd }}(\%)$ & 1.103 & $\uparrow$ & - & 0.079 & 1968 & 0.224 & 23.89 & 31.23 & $30.72 \%$ \\
\hline$S C_{\mathrm{md}}\left(\mathrm{kg} \mathrm{m}^{-3}\right)$ & -4.139 & $\downarrow$ & $* *$ & -4.700 & 1994 & 0.0003 & 708.31 & 485.13 & $-31.50 \%$ \\
\hline
\end{tabular}

' $\downarrow$ ' indicates a downward trend; ' $\uparrow$ ' indicates an upward trend.

'**' and '*' indicate significance levels of 0.01 and 0.05 , respectively; ' - ' indicates that the significance level exceeds 0.05 .

significantly $(p<0.05)$ at a rate of $1493.34 \mathrm{ts}^{-1}$ year $^{-1}$, whereas the $P_{\text {Smd }}$ had an increasing trend of $0.079 \%$ year $^{-1}$ (not significant). These results indicated that the contribution of the maximum daily sediment load to the annual total progressively increased over the last 60 years. Moreover, the $S C_{\mathrm{md}}$ decreased rapidly at a rate of $4.7 \mathrm{~kg} \mathrm{~m}^{-3}$ years $^{-1}(p<0.01)$. As shown in Table VI, significant change points were detected for $Q_{\mathrm{md}}$ $(p<0.05), Q_{\text {smd }}(p<0.05)$ and $S C_{\mathrm{md}}(p<0.01)$ in 1996 , 1996 and 1994, respectively. The change points were nearly consistent with those of annual and flood season $R$, $S$ and $S C$ (1996). Furthermore, there were substantial decreases in $Q_{\mathrm{md}}, Q_{\mathrm{smd}}$ and $S C_{\mathrm{md}}$ by $55.12 \%, 64.05 \%$ and $31.50 \%$ after the changing points, respectively (Table VI).

\section{Contributions of human activities and climate variability}

Double mass curves of annual and flood season precipitation-streamflow and precipitation-sediment load relationships, along with the linear regression lines, were shown in Figure 10. Pronounced breakpoints existed between the two regression lines for both annual and flood season streamflow and sediment load, further confirming that the change pointes detected using the Pettitt method were reasonable. The slopes of the regression lines decreased after the change point, especially for the cumulative precipitation-sediment load regression lines.

Using the regression equations established before the transition year, the extrapolated average annual and flood season streamflow and sediment load were calculated, which are shown in Tables VII and VIII, respectively. As previously noted, the difference between the calculated and measured values in the post-change period was caused by the effects of human activities, while the residual was caused by precipitation changes. The estimated relative contributions of human activities and climate availability to the changes in streamflow are shown in Table VII, while those related to sediment load changes are represented in Table VIII.
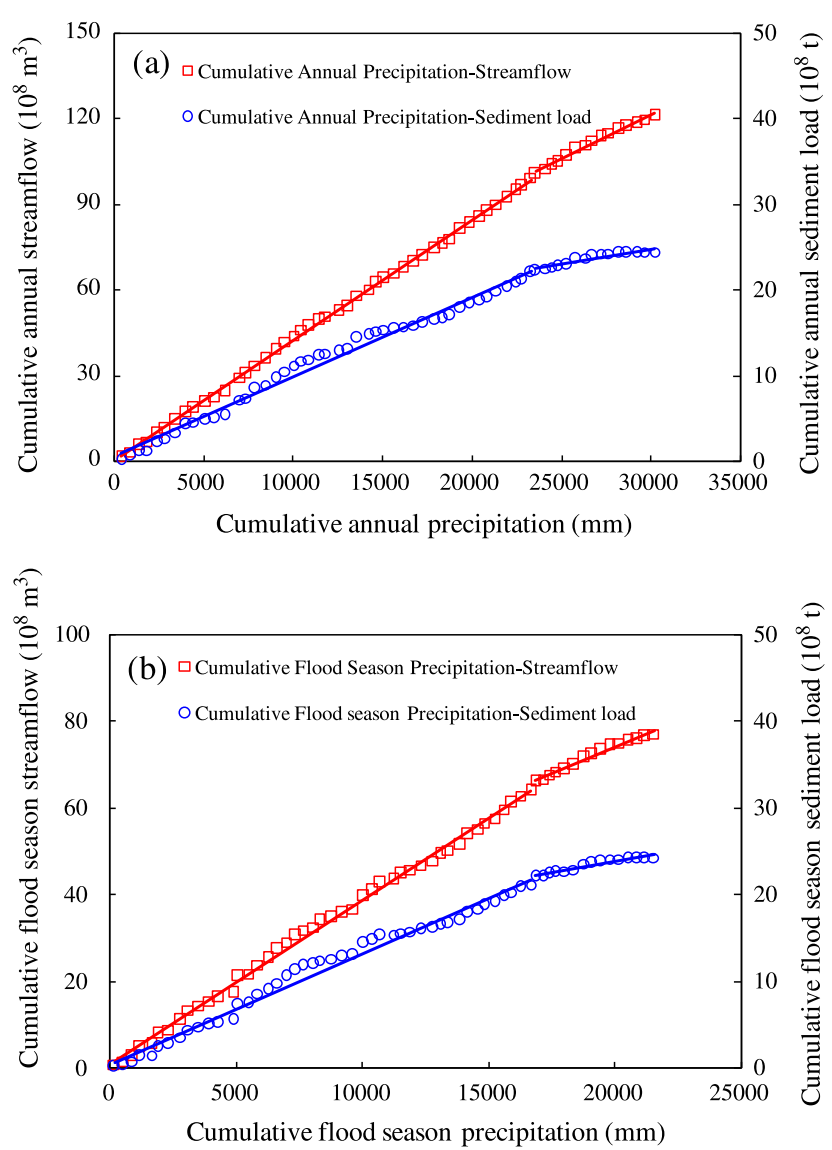

Figure 10. Double mass curves of (a) annual and (b) flood season precipitation-streamflow and precipitation-sediment load relationships. The straight lines are the regression lines of the cumulative data before and after the change point years

The contributions of human activities to annual and flood season streamflow reduction were $65.71 \%$ and $68.56 \%$, respectively, whereas the changes in precipitation only accounted for approximately one third of the total (Table VII). As shown in Table VIII, the contribution from human activities $(80 \%)$ on the reduction in sediment load was much larger than that 
Table VII. The effects of human activities (HA) and climate variability (CV) on the reductions of annual and flood season streamflow after the change point year (unit: $10^{8} \mathrm{~m}^{3}$ )

\begin{tabular}{|c|c|c|c|c|c|c|}
\hline & Period & $R_{\mathrm{O}}{ }^{\mathrm{a}}$ & $R_{\mathrm{c}}^{\mathrm{b}}$ & $\Delta R^{\mathrm{c}}$ & Impact by $\mathrm{HA}^{\mathrm{d}}$ & Impact by $\mathrm{CV}^{\mathrm{d}}$ \\
\hline \multirow[t]{2}{*}{ Annual scale } & 1952-1996 & 2.21 & 2.18 & & & \\
\hline & 1997-2011 & 1.44 & 1.95 & 0.77 & $0.51(65.71 \%)$ & $0.26(34.29 \%)$ \\
\hline \multirow[t]{2}{*}{ Flood season scale } & 1952-1996 & 1.45 & 1.42 & & & \\
\hline & 1997-2011 & 0.76 & 1.24 & 0.69 & $0.47(68.56 \%)$ & $0.22(31.44 \%)$ \\
\hline
\end{tabular}

Notes: ${ }^{a} R_{\mathrm{o}}$ indicates the observed average streamflow.

${ }^{\mathrm{b}} R_{\mathrm{c}}$ indicates the calculated average streamflow.

c $\Delta R$ indicates the reduction of average streamflow compared with the period before the change point year.

${ }^{\mathrm{d}}$ Data in parentheses indicate the impact percentage by HA and CV.

Table VIII. The effects of human activities (HA) and climate variability (CV) on the reductions of annual and flood season sediment load after the change point year (unit: $10^{4} \mathrm{t}$ )

\begin{tabular}{|c|c|c|c|c|c|c|}
\hline & Period & $S_{\mathrm{o}}{ }^{\mathrm{a}}$ & $S_{\mathrm{c}}{ }^{\mathrm{b}}$ & $\Delta S^{\mathrm{c}}$ & Impact of $\mathrm{HA}^{\mathrm{d}}$ & Impact of $\mathrm{CV}^{\mathrm{d}}$ \\
\hline \multirow[t]{2}{*}{ Annual scale } & 1952-1996 & 4912.79 & 4921.44 & & & \\
\hline & $1997-2011$ & 1541.68 & 4265.77 & 3371.11 & $2724.09(80.81 \%)$ & $647.02(19.19 \%)$ \\
\hline \multirow[t]{2}{*}{ Flood season scale } & 1952-1996 & 4860.18 & 4816.63 & & & \\
\hline & 1997-2011 & 1468.37 & 4161.46 & 3391.81 & $2673.09(79.40 \%)$ & $698.73(20.60 \%)$ \\
\hline
\end{tabular}

Notes: ${ }^{a} S_{\mathrm{o}}$ indicates the observed average sediment load.

${ }^{b} S_{\mathrm{c}}$ indicates the calculated average sediment load.

${ }^{\mathrm{c}} \Delta S$ indicates the reduction of average sediment load compared with the period before the change point year.

${ }^{\mathrm{d}}$ Data in parentheses indicate the impact percentage by HA and CV.

from precipitation changes $(20 \%)$. The results suggested that the effects of human activities on annual and flood scales were nearly equal, while the effects of precipitation changes on streamflow was greater than those on sediment load. The human activities played a more substantial role for both streamflow and sediment load reductions in the watershed, while climate variability played a complementary role.

\section{DISCUSSION}

\section{Influence of climate variability}

The effects of climate variability on streamflow and sediment load variations are primarily related to changes in precipitation and potential evapotranspiration. Precipitation is the driving force for runoff and, therefore, directly influences the watershed streamflow and its sediment transport capacity. The potential evapotranspiration represents the integrated effect of climate variables, indicating the potential water loss capacity. In this study, only a slight and insignificant reduction in the annual precipitation and an increase in the annual potential evapotranspiration were observed in the watershed from 1952 to 2011. In contrast, the streamflow and sediment load underwent more noticeable reductions. Furthermore, the watershed had a significant change point (1996) with respect to both the streamflow and sediment load, but the precipitation and potential evapotranspiration did not exhibit a similar change point. Moreover, the streamflow and sediment load decreased by approximately $40 \%$ and $70 \%$ after the change point, respectively. However, the precipitation and potential evapotranspiration only decreased by $10 \%$ and increased by $5 \%$ after 1996 , respectively.

With respect to the slight decrease in the precipitation amount, the streamflow and sediment load production ability of precipitation decreased substantially according to the significant reductions in the runoff and sediment coefficients on both annual and flood season scales (Tables III and IV). Figure 11 shows the relationships between annual precipitation and streamflow and sediment load in the two periods separated by the abrupt change points, and the corresponding relationships on flood season scale are shown in Figure 12. The correlations of the precipitation-streamflow and precipitation-sediment load relationships before the change point were much stronger than those after the change point. Yao et al. (2011) also indicated that there was a relatively strong relationship between the runoff, sediment load and precipitation before the 1970s with high coefficients of $>0.70$ for most of the catchments in 

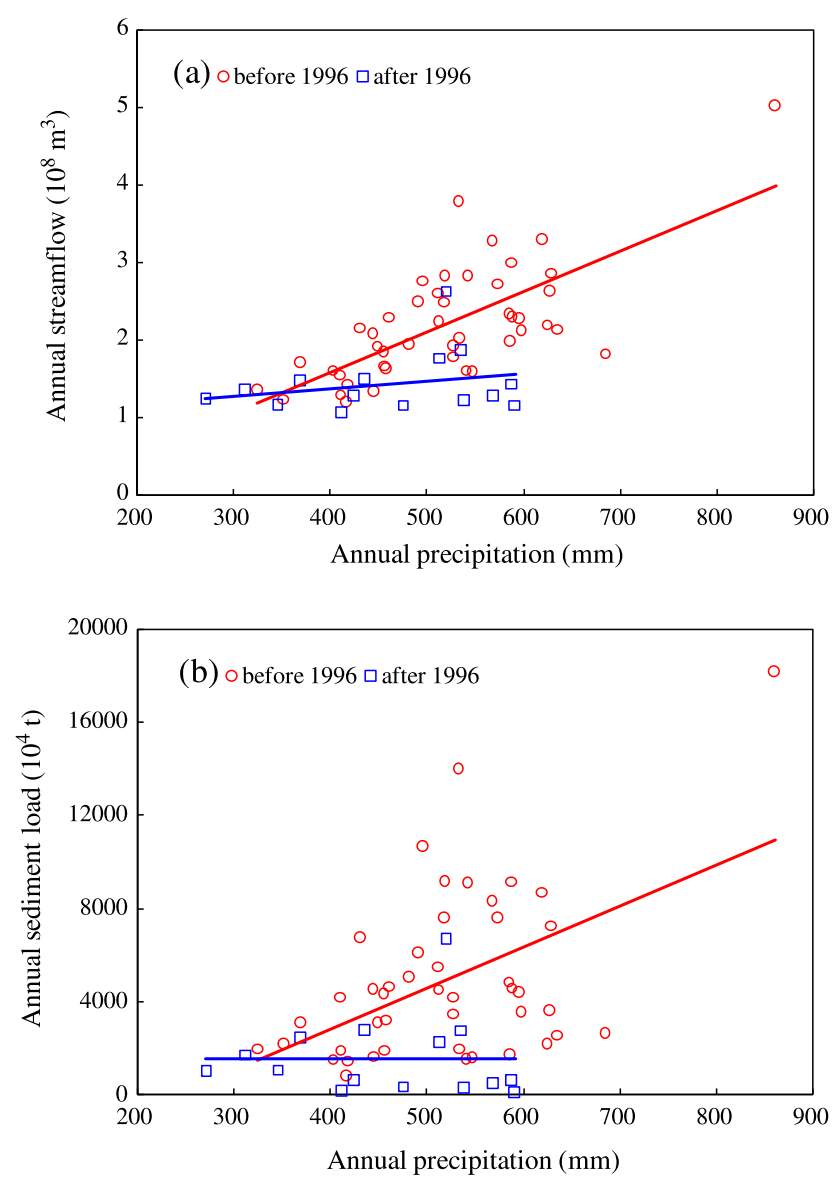

Figure 11. The relationship between annual (a) precipitation-streamflow and (b) precipitation-sediment load during the two periods divided by the change point year. The solid line is the linear regression line

the MRYRB, whereas the relationship became weaker between 2000 and 2006. The correlation between the annual runoff, sediment load and erosive rainfall in the Beiluo River basin was weaker during 2000-2009 compared with that before 1999 (Tian et al., 2015).

Furthermore, the regression trend lines after the change point were situated below the lines before the change period (Figures 11 and 12). This implied that with the same precipitation, the amount of streamflow and sediment load generation during the post-change period was less than that during the pre-change period. As shown in Figures 11 and 12, the slope of the regression line during the post-change period was nearly zero, indicating that the increase of precipitation did not result in any increase of the streamflow and especially the sediment load. This further confirmed that the effects of precipitation on streamflow and sediment load decreased substantially after the change point.

The aforementioned analysis supported that the climate variability was not the main driving force for the significant reductions in streamflow and sediment load
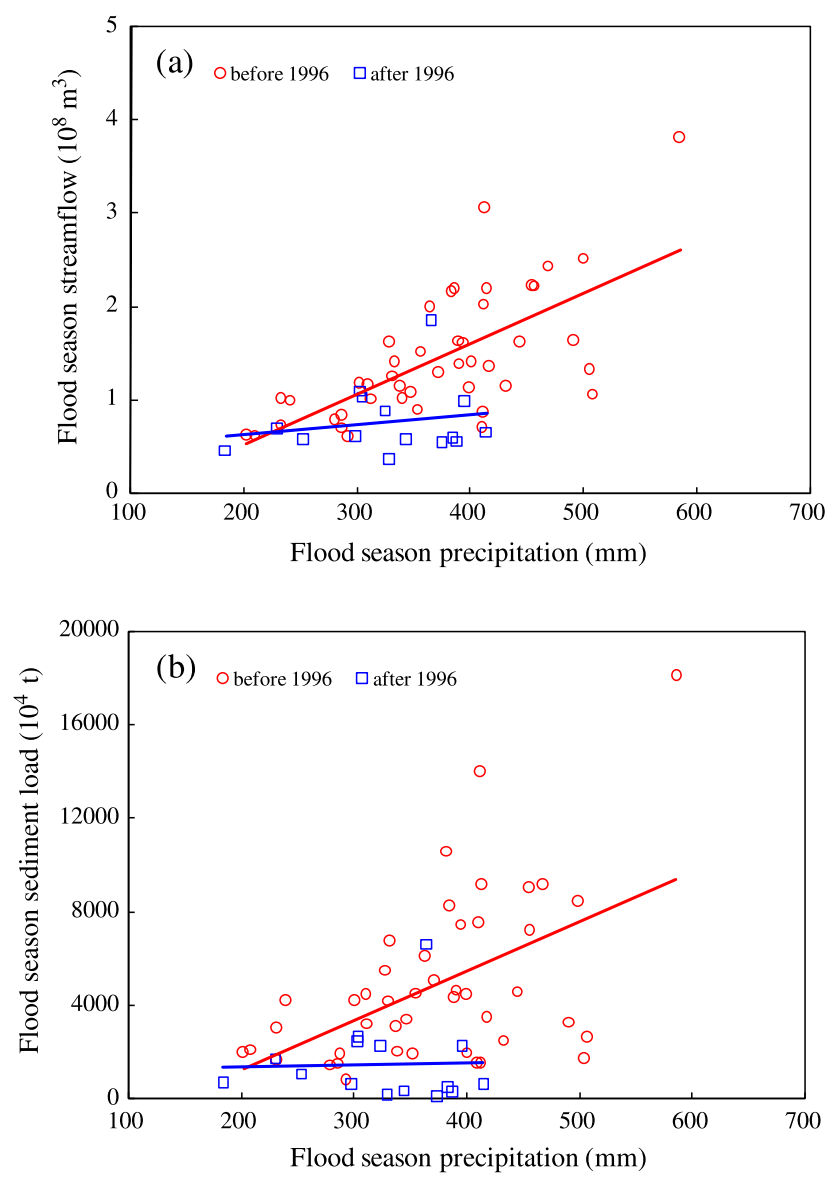

Figure 12. The relationship between flood season (a) precipitationstreamflow and (b) precipitation-sediment load during the two periods divided by the change point year. The solid line is the linear regression line

and intensive human activities played a main role. Zhao et al. (2014) indicated that precipitation at all of the stations in the MRYRB had negative trends during $1950 \mathrm{~s}-2010\left(-4.7 \mathrm{~mm}\right.$ year $^{-1}$ to $\left.-0.19 \mathrm{~mm} \mathrm{year}^{-1}\right)$ and temperature increased significantly at most stations, while PET showed a mixed of upward and downward trend. The estimated contributions of climate variability by Budyko's curve and linear regression method for annual streamflow reduction in the Yanhe watershed were 56.2\% and $18.2 \%$, respectively (Zhao et al., 2014). In Gao et al. (2014), the climate variability and non-climate factors were estimated to have contributed almost equally ( $49 \%$ vs $51 \%$ ) to the annual streamflow reduction with the sensitivity-based method. Li et al. (2014) found that the contribution of precipitation on runoff reduction was $31.6 \%$ with the elasticity analysis. In this study, the contribution of climate variability to annual streamflow reduction was estimated to be $34 \%$ by the mass curve method. The differences between the results are mainly caused by the assumptions of different methods, which needs further investigation. 


\section{Influence of human activity}

The human activities primarily include the ecological restoration campaigns and soil and water conservation measures. The GFG project was the largest land retirement programme. Implement at the end of 1990s, the GFG project aimed to convert croplands and abandoned farmlands on steep slopes to forest and pasture lands. The arable land in the Yanhe watershed increased gradually before 2000 . The area of arable land was $2582.86,2816.9$ and $3198.83 \mathrm{~km}^{2}$ in 1975,1990 and 2000, respectively. However, with the launching of the GFG project, the arable land area sharply decreased to $1349.07 \mathrm{~km}^{2}$ in 2008 . Undoubtedly, the GFG project contributed largely to reductions in runoff and sediment production on the sloping terrain (Zhang et al., 2008; Rustomji et al., 2008; Feng et al., 2012).

The soil and water conservation measures include both biological (e.g. afforestation and planting grass) and engineering (e.g. creation of level terraces, building check dams and gully control projects) measures. The area of soil and water conservation measures in the Yanhe watershed increased evidently between 1959 and 2006 (Figure 13). The percentage of the total treated area increased from $0.85 \%$ in 1959 to $28.47 \%$ in 1996 , and reached $45.81 \%$ in 2006. The rate of increase was greatest during the $1980 \mathrm{~s}$ due to comprehensive management of small watersheds and after 1996 as a result of the implementation of the GFG project since 1999. Although the engineering measures were utilized over much smaller areas than the biological measures (Figure 13), these techniques were expected to have immediate and substantial effects on streamflow and sediment. As the conservation area expanded, the measures against soil erosion became increasingly effective, particularly since the late 1970s.

Afforestation and grass planting can alter a catchment's water balance by increasing rainfall interception and

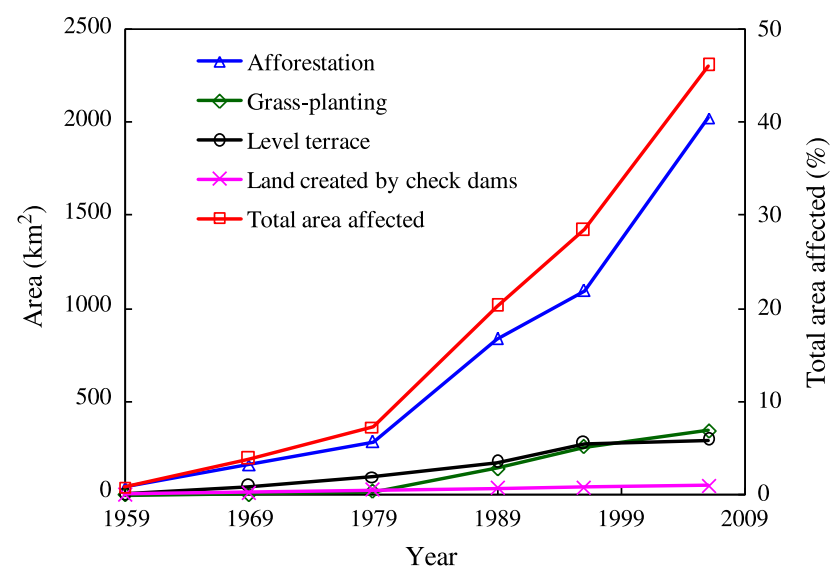

Figure 13. Accumulative area affected by soil and water conservation measures in the watershed from 1959 to 2006 evapotranspiration, enhancing infiltration and ultimately reducing runoff amount. Moreover, bark crack and leaf litter after afforestation and grass planting can increase the roughness of the soil surface, which can decrease the runoff velocity (Miao et al., 2010). Therefore, soil erosion and sediment transport subsequently decreased due to the decreasing surface runoff and increasing water infiltration into the soil. Sun et al. (2006) estimated that afforestation reduced $50 \%$ of the potential water yield by enhancing evapotranspiration in the Loess Plateau. The literature review study of McVicar et al. (2007) indicated that the annual streamflow was reduced by between $10 \%$ and $70 \%$ as a result of afforestation in the Loess Plateau region. As shown in Figure 13, the area in the upstream of the GHS that was afforested or planted by grass increased from 1959 to 2006 , especially since 1979 . The total area of afforestation and grass planting increased from $41.66 \mathrm{~km}^{2}$ in 1959 to $1360.07 \mathrm{~km}^{2}$ in 1996 , and reached $2370.05 \mathrm{~km}^{2}$ in 2006 accounting for approximately $40 \%$ of the watershed area.

Most of terraces in the Loess Plateau are level, which changes the local microtopography and greatly reduces the slope gradient. The creation of level terraces can enhance infiltration and reduce or stop overland flow, which can weaken the occurrence and transportation of sediment. It was previously reported that the creation of level terraces decreased the average runoff and sediment load by $86.70 \%$ and $95.00 \%$ in the middle reaches of Yellow River basin, respectively (Chen et al., 2004). The ratio for maintaining runoff and sediment by level terraces were found to be $3.8 \mathrm{~m}^{3} \mathrm{~km}^{-2}$ and $0.8 \mathrm{t} \mathrm{km}^{-2}$, respectively (Miao et al., 2011). In the Yanhe watershed, the area of level terraces in the upstream of the GHS significantly increased substantially from $4.13 \mathrm{~km}^{2}$ in 1959 to $275.60 \mathrm{~km}^{2}$ in 1996 , and reached $296.45 \mathrm{~km}^{2}$ in 2006 .

Building check dams has been the most effective measure to retain sediment (Xu et al., 2004). The effects of check dams can be expressed by the area of land created above them. The rate at which check dams retaining sediment in the Loess Plateau was estimated to be approximately $5.15-13.08 \times 10^{4} \mathrm{t} \mathrm{hm}^{-2}$ (Ran et al., 2012). Moreover, previous work has shown that the check dams reduced the catchment sediment yield by up to $77 \%$ in the Rogativa catchment (Murcia, Spain) (Boix-Fayos et al., 2007). Xu et al. (2013) estimated that the runoff and sediment in the rainy reason were reduced by up to $28.9 \%$ and $85.5 \%$ due to check dams in the Yanhe watershed, respectively. By the end of 2002, there were 7872 check dams including 57 large check dams and 7815 medium and small check dams in the Yanhe watershed (Ran et al., 2012). The area created by check dams in the upstream of the GHS increased from $4.62 \mathrm{~km}^{2}$ in 1959 to $41.67 \mathrm{~km}^{2}$ in 1996 , and reached $49.5 \mathrm{~km}^{2}$ in 2006. There was $1554.5 \times 10^{6} \mathrm{~m}^{3}$ of sedimentation behind the check dams in 1996 (Wang et al., 2013). 
Gully prevention and control measures include the establishment of grassed waterways and check dams with drop structures, and no tillage, topsoil compaction, doubling drilling and the establishment of grass and shrub hedges were also typically used (Poesen et al., 2003). These gully erosion control measures, which led to sediment deposition and vegetation reestablishment, create new hydraulic conditions to control runoff and sediment evacuation (Nyssen et al., 2004). There were 43 key projects for gully control in the watershed up to 1996. The control area and capacity of these projects were approximately $3.0 \mathrm{~km}^{2}$ and $38.0 \times 10^{6} \mathrm{~m}^{3}$, respectively. Moreover, there was also $18.8 \times 10^{6} \mathrm{~m}^{3}$ of sediment accumulated due to the gully erosion control projects since the 1980s (Wang et al., 2013).

In addition to the aforementioned soil and water conversation measures, the construction of water control projects such as reservoir also contributed to the reduction in streamflow and sediment load. Three reservoirs were constructed in the watershed in the 1970s with total storage capacity of $224.6 \times 10^{6} \mathrm{~m}^{3}$. These reservoirs provided water for domestic water use and irrigation to fulfil the increased demand for water resources caused by national economic development. However, the terrible reservoir siltation, though undesirable, has reduced sediment discharge in the mainstream. The cumulative siltation in 1979,1989 and 1997 were 62.58, 88.80 and $104.53 \times 10^{6} \mathrm{~m}^{3}$, respectively (Ran et al., 2012). Accordingly, the total siltation in the 1970s, 1980s and 1990s were $62.58,26.22$ and $15.73 \times 10^{6} \mathrm{~m}^{3}$, respectively. The reservoir siltation began decreasing in the 1980 s due to the decreased erosion in the upstream area of the reservoirs.

The applied soil and water conservation measures not only notably reduced the streamflow and sediment load, but they also intercepted the coarse sand transport into the river and made the sediment grain in the river increasingly fine. As shown in Table IX, the percentage of fine grains $(<0.025 \mathrm{~mm})$ increased from $40.4 \%$ during 1963-1979 to $54.8 \%$ during 1997-2006, whereas the coarse sand $(>0.1 \mathrm{~mm})$ decreased from $8.3 \%$ to $6.1 \%$. This phenomenon was beneficial for reducing bed aggradation and especially for mitigating the rise of the riverbed along the lower reaches of the Yellow River.

It was generally accepted that soil and water conservation measures played major roles in the reductions of runoff and especially sediment load in the watersheds in the Loess Plateau (Rustomji et al., 2008; Feng et al., 2012; Gao et al., 2012). Rustomji et al. (2008) found that soil and water conservation measures accounted for the majority (64\% to $89 \%$ ) of the reduction in annual sediment yield in most catchments in the Coarse Sandy Hilly Catchments region. Gao et al. (2012) indicated that the implementation of soil and water conservation measures reduced the sediment generation by $55.4 \%$ for seven catchments in the MRYRB
Table IX. The temporal variations of sediment grain size distribution at the hydrological station

\begin{tabular}{lcccc}
\hline & \multicolumn{4}{c}{ Sediment grain size distribution $(\%)$} \\
\cline { 2 - 5 } Period & $<0.025 \mathrm{~mm}$ & $0.025-0.05 \mathrm{~mm}$ & $0.05-0.1 \mathrm{~mm}>0.1 \mathrm{~mm}$ \\
\hline $1963-1979$ & 40.4 & 29.9 & 21.4 & 8.3 \\
$1980-1989$ & 43.8 & 31.5 & 19.0 & 5.6 \\
$1990-1996$ & 47.5 & 29.2 & 17.7 & 5.6 \\
$1997-2006$ & 54.8 & 24.7 & 14.4 & 6.1 \\
\hline
\end{tabular}

since the GFG project. For the Yanhe watershed, Wang et al. (2013) indicated that about $56 \mathrm{Mt}$ of sediment was silted annually from 1960-1999, which was larger than the amount of sediment leaving the basin per year $(41.05 \mathrm{Mt})$. This was a substantial indication that the soil and water conservation measures had a significant impact on runoff and sediment loss. This observation was consistent with our results.

The soil and water conservation measures started in the 1950 s, and accelerated after the 1980s and grew rapidly with the implementation of the GFG project. The progress of measures construction resulted in that the annual streamflow and sediment load gradually decreased since 1952 and declined abruptly in 1996. The soil and water conservation measures reduced the conversion of rainfall to runoff and increased soil water storage (Gao et al., 2014). They significantly decreased the streamflow and sediment during flood season especially in July and August, and reduced the extreme daily hydrological regime. As a result of soil water storage, there were no significant seasonal trends in the dry season. Furthermore, the soil and water conservation measures led to a reduction in high-flow but increases in low-flow in daily flow duration curves (Gao et al., 2014).

\section{Further scopes of this study}

The effects of intensive human activities on runoff and sediment load varied during different stages, and the role of each human activity changed with different temporal scales. Furthermore, there were another four hydrological stations (Ansai, Xinghe, Yan'an and Zaoyuan) in the upper and middle reaches of the Yanhe watershed. Gao et al. (2015) found that all the five stations experienced evident reductions in streamflow and sediment load, but the reduction became higher from upstream to the midstream and downstream stations. The observation at the Ganguyi station represented the streamflow and sediment exported from the entire basin. The distribution of hydrological changes and effects of human activities among the watershed should be considered. In the future, hydrological model simulations combined with more detailed data will be used to demonstrate the streamflow and sediment load changes on different temporal-spatial 
scales and detect the driving mechanism of human activities and climate variability in a more precise way.

\section{CONCLUSIONS}

The annual precipitation in the Yanhe watershed exhibited decreasing trend of -0.889 mmyear $^{-1}$ over the last 60 years, whereas the annual potential evapotranspiration and aridity index increased by $0.478 \mathrm{mmyear}^{-1}$ and 0.001 year $^{-1}$, respectively. However, no significant trends were identified for these three climate variables. Both the annual and flood season streamflow, sediment load, sediment concentration and sediment coefficient exhibited significant decreasing trends $(p<0.01)$. A significant negative trend $(p<0.01)$ was detected for the flood season runoff coefficient, whereas the decreasing trend of annual value was not significant. The reductions in annual and flood season streamflow and sediment were primarily caused by the significant decreases during July-August. The maximum daily streamflow, sediment load and sediment concentration were all concentrated in JulyAugust and had significant decreasing trend $(p<0.01)$. However, the percentage of the maximum daily streamflow and sediment load accounting for the annual total exhibited non-significant decreasing and increasing trends, respectively. Human activities contributed more than climate variability to the reductions in streamflow $(67.13 \%$ vs $32.87 \%)$ and sediment load $(80.10 \%$ vs $19.90 \%)$. The increase of precipitation did not result in any increase of streamflow and sediment load during the post-change period. Afforestation and check-dams were the most effective soil and water conservation measures, which also made the sediment grain finer. In general, the results of this study indicated that there were close connections between streamflow and sediment load changes on different temporal scales. The soil and water conservation measures contributed to reducing the total sediment yield by both reducing runoff and also by impeding sediment mobility within the landscape.

\section{ACKNOWLEDGEMENTS}

This research was financially supported by the National Natural Science Foundation of China (41471094 and 41230745) and the Young Scientists Fund of RCEES (RCEES-QN-20130053 F). We are grateful to the Ecological Environment Database of Loess Plateau, the Yellow River Conservancy Commission and the National Meteorological Information Center for permitting us access to the hydrological and meteorological data.

\section{REFERENCES}

Allen RG, Pereira LS, Raes D, Smith M. 1998. Crop Evapotranspiration Guidelines for Computing Crop Water Requirements. FAO Irrigation and Drainage Paper No. 56: FAO, Rome.
Boix-Fayos C, Barbera GG, Lopez-Bermudez F, Castillo VM. 2007. Effects of check dams, reforestation and land-use changes on river channel morphology: case study of the Rogativa catchment (Murcia, Spain). Geomorphology 91: 103-123.

Chen JN, Wang YZ, Xu JH. 2004. The influences of Soil and Water Conservation on the Water Resource and Sediment in the Loess Plateau. Yellow River Water Conservancy Press: Zhengzhou, China (in Chinese).

Chu ZX, Zhai SK, Lu XX, Liu JP, Xu JX, Xu KH. 2009. A quantitative assessment of human impacts on decrease in sediment flux from major Chinese rivers entering the western Pacific Ocean. Geophysical Research Letters 36: L19603. DOI: 10.1029/2009GL039513.

Cohen S, Kettner AJ, Syvitski JPM. 2014. Global suspended sediment and water discharge dynamics between 1960 and 2010: continental trends and intra-basin sensitivity. Global and Planetary Change 115: 44-58.

Dou L, Huang MB, Hong Y. 2009. Statistical assessment of the impact of conservation measures on streamflow responses in a watershed of the Loess Plateau, China. Water Resources Management 23: 1935-1949.

Feng XM, Sun G, Fu BJ, Su CH, Liu Y, Lamparski H. 2012. Regional effects of vegetation restoration on water yield across the Loess Plateau, China. Hydrology and Earth System Sciences 16: 2617-2628.

Gao GY, Fu BJ, Ma Y. 2015. Temporal variations of streamflow, sediment load and flow-sediment relationship in the Yanhe watershed of the Chinese Loess Plateau. (unpublished paper).

Gao P, Geissen V, Ritsema CJ, Mu XM, Wang F. 2013. Impact of climate change and anthropogenic activities on stream flow and sediment discharge in the Wei River basin, China. Hydrology and Earth System Sciences 17: 961-972.

Gao P, Jiang GT, Wei YP, Mu XM, Wang F, Zhao GJ, Sun WY. 2014. Streamflow regimes of the Yanhe River under climate and land use change, Loess Plateau, China. Hydrological Processes DOI: 10.1002/ hyp.10309.

Gao ZL, Fu YL, Li YH, Liu JX, Chen N, Zhang XP. 2012. Trends of streamflow, sediment load and their dynamic relation for the catchments in the middle reaches of the Yellow River over the past five decades. Hydrology and Earth System Sciences 16: 3219-3231.

Hirsch RM, Slack JR, Smith RA. 1982. Techniques of trend analysis for monthly water quality data. Water Resources Research 18: 107-121.

Huo ZL, Feng SY, Kang SZ, Li WC, Chen SJ. 2008. Effects of climate changes and water-related human activities on annual stream flows of the Shiyang river basin in arid north-west China. Hydrological Processes 22: 3155-3167.

Kendall MG. 1975. Rank Correlation Measures. Charles Griffin: London, UK. Li EH, Mu XM, Zhao GJ, Gao P, Shao HB. 2014. Variation of runoff and precipitation in the Hekou-Longmen region of the Yellow River based on elasticity analysis. The Scientific World Journal 929858, DOI: $10.1155 / 2014 / 929858$.

Li Z, Zheng FL, Liu WZ. 2012. Spatiotemporal characteristics of reference evapotranspiration during 1961-2009 and its projected changes during 2011-2099 on the Loess Plateau of China. Agricultural and Forest Meteorology 154-155: 147-155.

Liu XY, Yang ST, Dang SZ, Luo Y, Li XY, Zhou X. 2014. Response of sediment yield to vegetation restoration at a large spatial scale in the Loess Plateau. Science China-Technological Sciences 57: 1482-1489.

Mann HB. 1945. Nonparametric tests against trend. Econometrica 13(3): 245-259.

McVicar TR, Li LT, Van Niel TG, Zhang L, Li R, Yang QK, Zhang XP, Mu XM, Wen ZM, Liu WZ, Zhao YA, Liu ZH, Gao P. 2007. Developing a decision support tool for China's re-vegetation program: simulating regional impacts of afforestation on average annual streamflow in the Loess Plateau. Forest and Ecology Management 251: $65-81$.

Miao CY, Ni JR, Borthwick AGL. 2010. Recent changes of water discharge and sediment load in the Yellow River basin, China. Progress in Physical Geography 34: 541-561.

Miao CY, Ni JR, Borthwick AGL, Yang L. 2011. A preliminary estimate of human and natural contributions to the changes in water discharge and sediment load in the Yellow River. Global and Planetary Change 76: $196-205$.

Milliman JD, Farnsworth KL, Jones PD, Xu KH, Smith LC. 2008. Climatic and anthropogenic factors affecting river discharge to the global ocean, 1951-2000. Global and Planetary Change 62: 187-194. 
Milly PCD, Dunne KA, Vecchia AV. 2005. Global pattern of trends in streamflow and water availability in a changing climate. Nature $\mathbf{4 3 8}$ : 347-350.

Mu XM, Zhang L, McVicar TR, Chille B, Gao P. 2007. Analysis of the impact of conservation measures on stream flow regime in catchments of the Loess Plateau, China. Hydrological Processes 21: 2124-2134.

Nyssen J, Veyret-Picot M, Poesen J, Moeyersons J, Haile M, Deckers J, Govers G. 2004. The effectiveness of loose rock check dams for gully control in Tigray, northern Ethiopia. Soil and Use Management 20: 55-64.

Peng J, Chen SL, Dong P. 2010. Temporal variation of sediment load in the Yellow River basin, China, and its impacts on the lower reaches and the river delta. Catena 83: 135-147.

Pettitt AN. 1979. A non-parametric approach to the change-point problem. Applied Statistics 28(2): 126-135.

Poesen J, Nachtergaele J, Verstraeten G, Valentin C. 2003. Gully erosion and environmental change: importance and research needs. Catena 50: 91-133.

Ran DC, Liu LW, Zhao LY, Bai ZG, Liu B, Wang H. 2000. The Changes of Soil and Water Conservation, Streamflow and Sediment in HekouLongmen Region in Middle Reaches of Yellow River. Yellow River Water Conservancy Press: Zhengzhou, China (in Chinese).

Ran DC, Zuo ZG, Wu YH, Li XM, Li ZH. 2012. Responses of Streamflow and Sediment Changes during Recent Period to Human Activities in the Middle Reaches of Yellow River. Science Press: Beijing, China (in Chinese).

Rustomji P, Zhang XP, Hairsine PB, Zhang L, Zhao J. 2008. River sediment load and concentration responses to changes in hydrology and catchment management in the Loess Plateau of China. Water Resources Research 44: W00A04. DOI: 10.1029/2007WR006656

Sen PK. 1968. Estimates of the regression coefficient based on Kendall's tau. Journal of the American Statistical Association 63: 1379-1389.

Sun G, Zhou G, Zhang Z, Wei X. 2006. Potential water yield reduction due to forestation across China. Journal of Hydrology 328: 548-558.

Thornthwaite CW. 1948. An approach toward a rational classification of climate. Geographical Review 38: 55-94.

Tian P, Zhai JQ, Zhao GJ, Mu XM. 2015. Dynamics of runoff and suspended sediment transport in a highly erodible catchment of the Chinese Loess Plateau. Land Degradation \& Development. DOI: 10.1002/Idr.2373

Walling DE, Fang D. 2003. Recent trends in the suspended sediment loads of the world rivers. Global and Planetary Change 39: 111-126.
Wan L, Zhang XP, Ma Q, Zhang JJ, Ma TY, Sun YP. 2014. Spatiotemporal characteristics of precipitation and extreme events on the Loess Plateau of China between 1957 and 2009. Hydrological Processes 28(18): 4971-4983.

Wang F, Mu X, Hessel R, Zhang W, Ritsema CJ, Li R. 2013. Runoff and sediment load of the Yan River, China: changes over the last $60 \mathrm{yr}$. Hydrology and Earth System Sciences 17: 2515-2527.

Wang QX, Fan XH, Qin Z, Wang MB. 2012. Change trends of temperature and precipitation in the Loess Plateau Region of China, 1961-2010. Global and Planetary Change 92-93: 138-147.

Xu KH, Milliman JD, Xu H. 2010. Temporal trend of precipitation and runoff in major Chinese Rivers since 1951. Global and Planetary Change 73: 219-232.

Xu XZ, Zhang HW, Zhang O. 2004. Development of check-dam systems in gullies on the Loess Plateau, China. Environmental Science \& Policy 7: 79-86.

Xu XL, Scanlon BR, Schilling K, Sun A. 2013a. Relative importance of climate and land surface changes on hydrologic changes in the US Midwest since the 1930s: Implications for biofuel production. Journal of Hydrology 497: 110-120.

Xu XL, Liu W, Rafique R, Wang KL. 2013b. Revisiting continental U.S. hydrologic change in the latter half of the 20th century. Water Resources Management 27: 4337-4348.

Xu YD, Fu BJ, He CS. 2013. Assessing the hydrological effect of check dams in the Loess Plateau, China, by model simulations. Hydrology and Earth System Sciences 17: 2185-2193.

Yao WY, Xu JH, Ran DC. 2011. Assessment of changing trends in streamflow and sediment fluxes in the Yellow River basin. Yellow River Water Conservancy Press: Zhengzhou, China (in Chinese).

Yue S, Wang CY. 2002. Applicability of prewhitening to eliminate the influence of serial correlation on the Mann-Kendall test. Water Resources Research 38: 1068. DOI: 10.1029/2001WR000861

Zhang XP, Zhang L, Zhao J, Rustomji P, Hairsine P. 2008. Responses of streamflow to changes in climate and land use/cover in the Loess Plateau, China. Water Resources Research 44: W00A07. DOI: 10.1029/ 2007WR006711

Zhao GJ, Tian P, Mu XM, Jiao JY, Wang F, Gao P. 2014. Quantifying the impact of climate variability and human activities on streamflow in the middle reaches of the Yellow River basin, China. Journal of Hydrology 519: $387-398$. 